\title{
Reducing Amyloid-Related Alzheimer's Disease Pathogenesis by a Small Molecule Targeting Filamin A
}

\author{
Hoau-Yan Wang, ${ }^{1,2}$ Kalindi Bakshi, ${ }^{1}$ Maya Frankfurt, ${ }^{3}$ Andres Stucky, ${ }^{1,2}$ Marissa Goberdhan, ${ }^{1,2}$ Sanket M. Shah, ${ }^{1}$ \\ and Lindsay H. Burns ${ }^{4}$ \\ ${ }^{1}$ Department of Physiology, Pharmacology and Neuroscience, City University of New York Medical School, New York, New York 10031, 2Department of \\ Biology and Neuroscience, Graduate School of the City University of New York, New York, New York 10016, ${ }^{3}$ Department of Science Education, Hofstra \\ North Shore-Long Island Jewish School of Medicine, Hempstead, New York 11549-1000, and ${ }^{4}$ Pain Therapeutics, Inc., Austin, Texas 78731
}

PTI-125 is a novel compound demonstrating a promising new approach to treating Alzheimer's disease (AD), characterized by neurodegeneration and amyloid plaque and neurofibrillary pathologies. We show that the toxic signaling of amyloid- $\beta_{42}\left(\mathrm{~A} \beta_{42}\right)$ by the $\alpha 7-$ nicotinic acetylcholine receptor $(\alpha 7 \mathrm{nAChR})$, which results in tau phosphorylation and formation of neurofibrillary tangles, requires the recruitment of the scaffolding protein filamin A (FLNA). By binding FLNA with high affinity, PTI- 125 prevents A $\beta_{42}$ 's toxic cascade, decreasing phospho-tau and $\mathrm{A} \beta$ aggregates and reducing the dysfunction of $\alpha 7 \mathrm{nAChRs,} \mathrm{NMDARs,} \mathrm{and} \mathrm{insulin} \mathrm{receptors.} \mathrm{PTI-125}$ prevents $\mathrm{A} \beta_{42}$ signaling by drastically reducing its affinity for $\alpha 7 \mathrm{nAChRs}$ and can even dissociate existing $\mathrm{A} \beta_{42}-\alpha 7 \mathrm{nAChR}$ complexes. Additionally, PTI- 125 prevents A $\beta$-induced inflammatory cytokine release by blocking FLNA recruitment to toll-like receptor 4, illustrating an anti-inflammatory effect. PTI-125's broad spectrum of beneficial effects is demonstrated here in an intracerebroventricular $\mathrm{A} \beta_{42}$ infusion mouse model of $\mathrm{AD}$ and in human postmortem $\mathrm{AD}$ brain tissue.

\section{Introduction}

Alzheimer's disease $(\mathrm{AD})$ represents one of the greatest health care burdens, affecting 35 million persons worldwide and an estimated 115 million persons by 2050 (Wimo and Prince, 2010). $\mathrm{AD}$ is a devastating dementia that first presents as progressive memory loss and later can include neuropsychiatric symptoms. Diagnosis is confirmed at autopsy by amyloid deposits and neurofibrillary tangles (NFTs) containing the microtubuleassociated protein tau. This neuropathology is estimated to precede symptoms by 10 years (Trojanowski et al., 2010). Current $\mathrm{AD}$ treatment is limited to acetylcholinesterase inhibitors, with mild and short-lived cognitive enhancement, and memantine, an NMDAR antagonist that may delay some later stage symptoms.

Amyloid- $\beta(A \beta)$, in particular $A \beta_{42}$, is commonly recognized as the principal causative agent in $\mathrm{AD}$, though its mechanism is debated. Cognitive impairment and the magnitude of synaptic deficit in the $\mathrm{AD}$ brain are more highly correlated with soluble $\mathrm{A} \beta$ than with the abundance of amyloid plaques, suggesting that

Received Jan. 24, 2012; revised March 16, 2012; accepted April 6, 2012.

Author contributions: H.-Y.W. designed research; H.-Y.W., K.P.B., M.F., A.S., M.G., and S.M.S. performed research; H.-Y.W. analyzed data; H.-Y.W. and L.H.B. wrote the paper.

This work was supported by Pain Therapeutics, Inc. We thank Drs. Nan-Horng (Stan) Lin and Yongmei Xu of Shanghai Medicilon, Inc., for the medicinal chemistry effort that led to PTI-125, a proprietary compound of Pain Therapeutics, Inc.

L.H.B. is an employee of and H.-Y.W. is a consultant for Pain Therapeutics, Inc. The rest of the authors declare no competing financial interests.

Correspondence should be addressed to Hoau-Yan Wang, Department of Physiology, Pharmacology and Neuroscience, City University of New York Medical School, 160 Convent Avenue, New York, NY 10031. E-mail: hywang@sci.ccny.cuny.edu.

DOI:10.1523/JNEUROSCI.0354-12.2012

Copyright $\odot 2012$ the authors $\quad 0270-6474 / 12 / 329773-12 \$ 15.00 / 0$ soluble $\mathrm{A} \beta$ inflicts synaptic impairment (Naslund et al., 2000). Robust evidence demonstrates that soluble $\mathrm{A} \beta$ elicits a toxic signaling cascade by the $\alpha 7$-nicotinic acetylcholine receptor $(\alpha 7 \mathrm{nAChR})$, leading to impaired synaptic activities, intraneuronal A $\beta_{42}$ aggregates, and cognitive deficits (Liu et al., 2001; Pettit et al., 2001; Chen et al., 2006; Dziewczapolski et al., 2009; Wang et al., 2009). This aberrant signaling activates the kinases ERK2 and JNK1, which phosphorylate tau, leading to the formation of NFTs (Wang et al., 2003).

$\mathrm{A} \beta_{42}$ binds $\alpha 7 \mathrm{nAChR}$ with femtomolar affinity (Wang et al., $2000 \mathrm{a}, \mathrm{b})$; therefore, to prevent $\mathrm{A} \beta_{42}$-induced $\alpha 7 \mathrm{nAChR}$ toxic signaling, anti- $A \beta$ therapies must either compete with this extremely high-affinity interaction or essentially eliminate all $A \beta_{42}$. After the initial femtomolar interaction, numerous $A \beta_{42}$ molecules bind the receptor, eventually causing internalization and amyloid plaques. These additional $\mathrm{A} \beta_{42}$ molecules appear to bind at a lower (picomolar) affinity (Wang et al., 2009); hence, it is possible to remove sufficient amounts of $\mathrm{A} \beta_{42}$ to prevent plaque formation without any impact on the toxic signaling by the highaffinity $\mathrm{A} \beta_{42}-\alpha 7 \mathrm{nAChR}$ interaction. Furthermore, pharmacotherapies aiming to prevent $\mathrm{A} \beta_{42}$ binding to $\alpha 7 \mathrm{nAChRs}$ by directly targeting the receptor could, unfortunately, alter $\alpha 7 \mathrm{nAChR}$ sensitivity or cell surface expression, especially if they surpass subpicomolar affinity. Alternative strategies to reduce $\mathrm{A} \beta_{42}$ signaling by $\alpha 7 \mathrm{nAChR}$ are needed.

We show here that $\mathrm{A} \beta_{42}$ toxic signaling requires the recruitment of the scaffolding protein filamin A (FLNA), which otherwise has very low levels of association with $\alpha 7 \mathrm{nAChR}$. Filamins are large cytoplasmic proteins best known for crosslinking actin but increasingly implicated in cell signaling (Stossel et al., 2001). PTI-125 binds FLNA with 200 femtomolar affinity to disrupt the 
$\mathrm{A} \beta$-induced FLNA recruitment to $\alpha 7 \mathrm{nAChRs}$ and to reduce $\mathrm{A} \beta_{42}$ signaling. PTI- 125 decreases $\mathrm{A} \beta_{42}$ affinity for $\alpha 7 \mathrm{nAChR}$, dissociating bound $\mathrm{A} \beta_{42}$. Additionally, PTI- 125 provides an antiinflammatory effect by similarly reducing FLNA association with toll-like receptor 4 (TLR4) and preventing cytokine release. $\mathrm{A} \beta_{42}$ activates TLR4 through CD14 (Reed-Geaghan et al., 2009), and we show this activation requires FLNA. Here we use an intracerebroventricular (ICV) $\mathrm{A} \beta_{42}$ infusion mouse model and human postmortem AD brain tissue to demonstrate PTI-125's promising potential as a novel therapeutic for $\mathrm{AD}$. We also examine FLNA $-\alpha 7 \mathrm{nAChR} / \mathrm{TLR} 4$ associations and $\mathrm{A} \beta_{42}-\alpha 7 \mathrm{nAChR}$ complexes in lymphocytes from $\mathrm{AD}$ patients as a potential $\mathrm{AD}$ diagnostic and biomarker.

\section{Materials and Methods}

Materials and chemicals. Leupeptin, aprotinin, phenylmethylsulfonyl fluoride (PMSF), pepstatin $\mathrm{A}$, soybean trypsin inhibitor, $\mathrm{NaF}$, sodium vanadate, $\beta$-glycerophosphate, 2-mercaptoethanol, glycine, Histopaque-1077, Tween-20, NP-40, anti- $\alpha$ nAChR (M-220), ATP, choline kinase, physostigmine sulfate, acetylcholine chloride, $\mathrm{AgNO}_{3}$, tetraphenylboran, $n$-butyronitrile, and digitonin were all purchased from Sigma. ${ }^{45} \mathrm{Ca}^{2+}(10$ $\mathrm{Ci} / \mathrm{mmol})$ and $\left[\right.$ methyl- $\left.{ }^{3} \mathrm{H}\right]$ choline chloride $(85.1 \mathrm{Ci} / \mathrm{mmol})$ were purchased from PerkinElmer. PNU282987 and NMDA were purchased from Tocris Bioscience. Anti- $\mathrm{pY}^{1150 / 1151} \mathrm{IR} \beta / \mathrm{pY}^{1135 / 1136} \mathrm{IGF}-1 \mathrm{R} \beta$ (44-804G), $-\mathrm{pY}{ }^{960} \operatorname{IR} \beta$ (44-800G), and $\mathrm{A} \beta_{1-42}$ were obtained from Invitrogen. AntiPSD-95 (05494) and -A $\beta_{42}$ (AB5739) and -NFTs (AB1518) were from Millipore Bioscience Research Reagents. Anti-phosphotyrosine (SC-508), $-\alpha 7 \mathrm{nAChR}$ (SC-5544, SC-65844), -FLNA (SC-28284, SC-271440), -IRS-1 (SC-8038), -TLR4 (SC-293072), -IR $\beta$ (SC-20739, SC-81465), -pY ${ }^{1150 / 1151}$ IR $\beta$ (SC-81500), -nNOS (SC-5302), -phospholipase C- $\gamma 1$ (SC-7290), -NR1 (SC-9058), -NR2A (SC-9056), -NR2B (SC-9057), -tau (SC-1995 [IP], SC$58860[\mathrm{WB}]$ ), -actin (SC-7210), and - $\beta$-actin (SC-47778) were all purchased from Santa Cruz Biotechnology. Anti- $\gamma \mathrm{PKC}$ (P82820) was from BD Transduction Laboratories, and anti-pY ${ }^{402} \mathrm{PyK} 2$ (A00498) and $-\mathrm{pY}^{416} \mathrm{Src}$ (A00396) were from GenScript. Anti-pSer ${ }^{202}$ tau (AT-8), anti-pThr ${ }^{231}$ tau (AT-180), anti-pThr ${ }^{181}$ (AT-270), Reacti-Bind NeutrAvidin High Binding Capacity Coated 96-well plates, covalently conjugated protein A-agarose beads, antigen elution buffer, and chemiluminescent reagents were purchased from Pierce-Endogen. SK-N-MC human neuroblastoma cells were purchased from American Type Culture Collection. All A $\beta$-derived peptides were dissolved in $50 \mathrm{~mm}$ Tris, $\mathrm{pH}$ 9.0, containing 10\% DMSO and were stored at $-80^{\circ} \mathrm{C}$. All test agents were freshly made according to the manufacturer's recommendation. If DMSO was used as the solvent, the highest DMSO concentration in the incubation medium was $1 \%$.

ICV A $\beta_{42}$ infusion mouse study. Eight-week-old male and female E129 mice $(30-35 \mathrm{~g})$ from Taconic were maintained on a $12 \mathrm{~h}$ light/dark cycle with food and water. All animal procedures comply with the National Institutes of Health Guide for the Care and Use of Laboratory Animals and were approved by the City College of New York Animal Care and Use Committee.

Mice anesthetized with $30 \mathrm{mg} / \mathrm{kg}$ sodium pentobarbital intraperitoneally were placed in a mouse stereotaxic surgery apparatus, as described previously (Wang et al., 2010). Mice receiving 7-day continuous ICV $\mathrm{A} \beta_{42}$ infusion were implanted with a minipump (Alzet) that delivers 0.1 $\mu \mathrm{l} / \mathrm{h}$ through a surgical glue-secured cannula placed in the left ventricle at the following coordinates: anteroposterior from bregma, $3.0 \mathrm{~mm}$; lateral, $1.0 \mathrm{~mm}$; horizontal, $3.0 \mathrm{~mm}$. The $\mathrm{A} \beta_{42}(0.2 \mathrm{nmol} / \mu \mathrm{l})$ was dissolved in $10 \%$ DMSO containing $50 \mathrm{~mm}$ Tris, $\mathrm{pH}$ 9.0, to prevent aggregation. Each mouse received $4.8 \mathrm{nmol}$ of $\mathrm{A} \beta_{42}$ daily for $7 \mathrm{~d}$. Each daily dose into the $35 \mu \mathrm{l}$ of CSF volume of a mouse would reach a concentration of 137 $\mu \mathrm{M}$, assuming no clearance. Control mice received a 7-day ICV infusion of vehicle.

To assess the effect of in vivo PTI-125 on $\mathrm{A} \beta_{42}$-elicited effects, mice received $10 \mathrm{mg} / \mathrm{kg}$ PTI- 125 by intraperitoneal injection daily for 2 weeks, starting on the day of surgery (day 1: $2 \mathrm{~h}$ after recovery from surgery; days 2-14, twice daily between 10 and 11 A.M. and between 3 and 4 P.M.). Twenty-four hours after the last injection, mice were killed by decapita- tion. Frontal cortex (FCX) and hippocampus from one half brain were homogenized and processed immediately after harvesting to obtain synaptosomes (P2 fraction), as described previously (Wang et al., 2003), for neuropharmacological assessments. Synaptosomes were washed twice and suspended in $2 \mathrm{ml}$ of ice-cold oxygenated Krebs-Ringer (K-R), containing (in mM): 25 HEPES, pH 7.4, $118 \mathrm{NaCl}, 4.8 \mathrm{KCl}, 25 \mathrm{NaHCO}_{3}, 1.3$ $\mathrm{CaCl}_{2}, 1.2 \mathrm{MgSO}_{4}, 1.2 \mathrm{KH}_{2} \mathrm{PO}_{4}, 10$ glucose, $100 \mu \mathrm{M}$ ascorbic acid, mixture of protease and protein phosphatase inhibitors (Roche Diagnostics) that had been aerated for $10 \mathrm{~min}$ with $95 \% \mathrm{O}_{2} / 5 \% \mathrm{CO}_{2}$. The protein concentration was determined using the Bradford method (Bio-Rad). The other brain halves were immersion fixed in cold $0.15 \mathrm{M}$ phosphatebuffered $10 \%$ formalin, $\mathrm{pH} 7.4$, and processed for immunohistochemical determinations of intraneuronal $\mathrm{A} \beta_{42}$ aggregates/plaques and NFTs as well as morphological integrity.

Postmortem human brain tissue study. This study protocol conformed to the tenets of the Declaration of Helsinki as reflected in a previous approval by the City College of New York and City University of New York Medical School human research committee. Each participant underwent a uniform clinical evaluation that included a medical history, complete neurological examination, cognitive testing including MiniMental state examination and other cognitive tests on episodic memory, semantic memory and language, working memory, perceptual speed, and visuospatial ability as well as psychiatric rating. Based on this information, subjects received AD diagnoses based on NINCDS-ADRDA criteria (McKhann et al., 1984). Postmortem brain tissue FCX from patients with clinically diagnosed sporadic $\mathrm{AD}$ and control tissues from healthy, age-matched, neurologically normal persons were obtained from the Harvard Brain Tissue Resource Center (HBTRC, Belmont, MA) and the UCLA Brain Tissue Resource Center (UBTRC, Los Angeles, CA). Both HBTRC and UBTRC are supported in part by the National Institutes of Health. The postmortem time intervals for collecting these brains were $\leq 13 \mathrm{~h}$ (mean postmortem intervals for collection of $\mathrm{AD}$ and control brain samples were $6.0 \pm 0.9 \mathrm{~h}$ and $5.8 \pm 0.8 \mathrm{~h}$, respectively). Diagnostic neuropathological examination was conducted on fixed sections stained with hematoxylin and eosin and with modified Bielschowsky silver staining (Yamamoto and Hirano, 1986) to establish any disease diagnosis according to defined criteria (Hyman and Trojanowski, 1997), and brain tissue from age-matched controls was similarly screened. The presence of both neuritic (amyloid) plaques and neurofibrillary tangles in all AD brains was confirmed by Nissl and Bielschowsky staining and characterized immunohistochemically with anti-A $\beta_{42}$ and -NFT staining in frontal and entorhinal cortex as well as hippocampus, as described previously (Wang et al., 2000a). Control tissues exhibited only minimal, localized microscopic neuropathology of $\mathrm{AD}(0-3$ neuritic plaques/ $10 \times$ field and 0-6 NFTs/10 $\times$ field in hippocampus). One gram blocks from Brodmann areas 10 and/or 46 of FCX were dissected using a band saw from fresh frozen coronal brain sections maintained at $-80^{\circ} \mathrm{C}$. All postmortem tissues were identified by an anonymous identification number, and experiments were performed as a best-matched pair without knowledge of clinical information.

For in vitro assessments, postmortem tissues were gradually thawed (from $-80^{\circ} \mathrm{C}$ to $-20^{\circ} \mathrm{C}$ ), sliced using a chilled McIlwain tissue chopper $(200 \mu \mathrm{m} \times 200 \mu \mathrm{m} \times 3 \mathrm{~mm})$ and suspended in ice-cold oxygenated K-R, containing (in mM): 25 HEPES, pH 7.4, $118 \mathrm{NaCl}, 4.8 \mathrm{KCl}, 1.3 \mathrm{CaCl}_{2}, 1.2$ $\mathrm{KH}_{2} \mathrm{PO}_{4}, 1.2 \mathrm{MgSO}_{4}, 25 \mathrm{NaHCO}_{3}, 10$ glucose, $100 \mu \mathrm{M}$ ascorbic acid, 50 $\mu \mathrm{g} / \mathrm{ml}$ of leupeptin, $0.2 \mathrm{PMSF}, 25 \mu \mathrm{g} / \mathrm{ml}$ pepstatin $\mathrm{A}$, and $0.01 \mathrm{U} / \mathrm{ml}$ soybean trypsin inhibitor $(\sim 20 \mathrm{mg} / 1 \mathrm{ml}$ of $\mathrm{K}-\mathrm{R})$. After centrifugation and two additional washes with $1 \mathrm{ml}$ of ice-cold $\mathrm{K}-\mathrm{R}$, brain slices were suspended in $1 \mathrm{ml}$ of $\mathrm{K}-\mathrm{R}$.

To examine the effects of exogenous $\mathrm{A} \beta_{42}, \sim 20 \mathrm{mg}$ of FCX from control subjects was incubated with $0.1 \mu \mathrm{M} \mathrm{A} \beta_{42}$ at $37^{\circ} \mathrm{C}$ for $70 \mathrm{~min}$. To test the effects of PTI- 125 on $\mathrm{A} \beta_{42}$-incubated control and native $\mathrm{AD}$ tissues, $\mathrm{PTI}-125$ ( 0.1 and $1 \mathrm{nM}$ ) was added $10 \mathrm{~min}$ after $0.1 \mu \mathrm{M} \mathrm{A} \beta_{42}$. Incubation continued for $1 \mathrm{~h}$ in the dark. The incubation mixture in a total incubation volume of $0.5 \mathrm{ml}$ was aerated for $1 \mathrm{~min}$ every $15 \mathrm{~min}$ with $95 \% \mathrm{O}_{2} / 5 \% \mathrm{CO}_{2}$. Reaction was terminated by the addition of $1.5 \mathrm{ml}$ of ice-cold $\mathrm{Ca}^{2+}$-free $\mathrm{K}-\mathrm{R}$, and slices were collected by a brief centrifugation.

To assess the effects of various $\alpha 7 \mathrm{nAChR}$ agents on $\alpha 7 \mathrm{nAChR}-\mathrm{nLNA}$ linkages, $\sim 20 \mathrm{mg}$ of FCX from control subjects was incubated with $1 \mu \mathrm{M}$ 
A

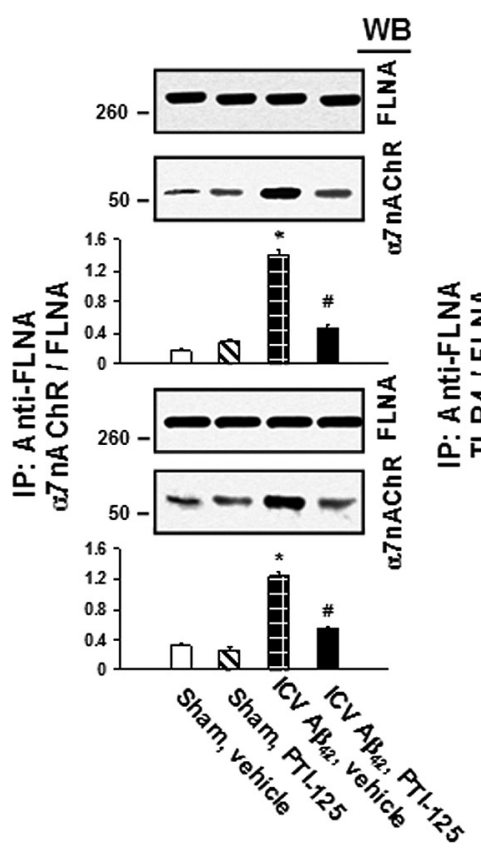

B

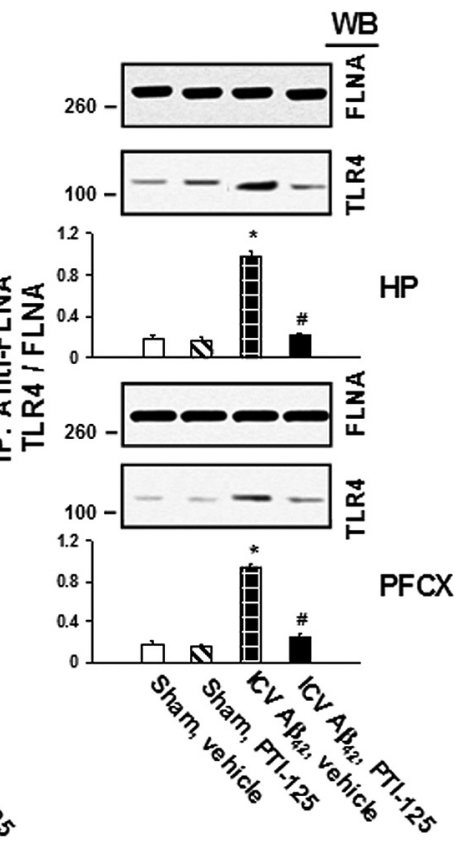

C

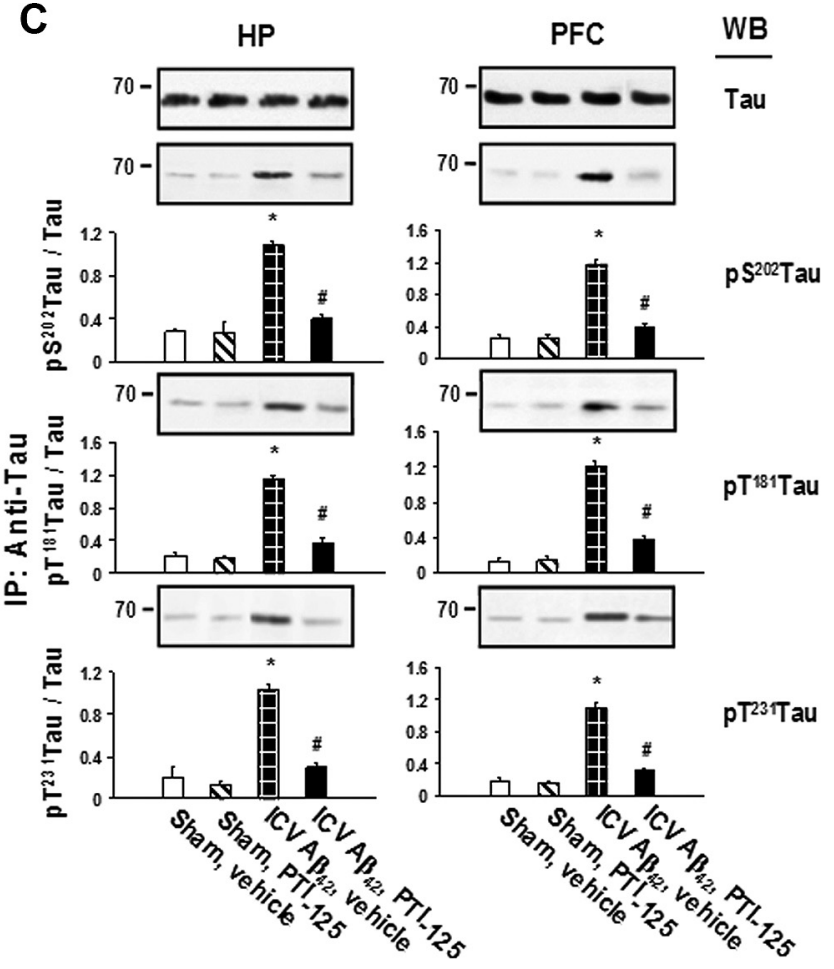

Figure 1. $A$, Continuous ICV A $\beta_{42}$ infusion for 1 week increased FLNA association with $\alpha 7 \mathrm{nAChR}$, and twice-daily intraperitoneal injections of PTI-125 for 2 weeks significantly reduced this

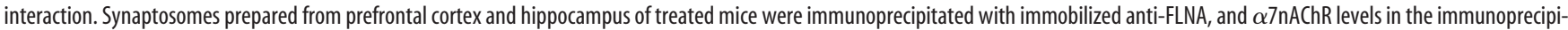
tates were detected by Western blot (WB) using an $\alpha 7 \mathrm{nAChR}$-specific antibody. $\boldsymbol{B}$, ICV $A \beta_{42}$ infusion also increased FLNA association with TLR4, detected in the same anti-FLNA immunoprecipitates with a TLR4-specific antibody. C, $\mathrm{A} \beta_{42}$ strongly promoted tau phosphorylation at $\mathrm{Ser}^{202}$, $\mathrm{Thr}^{231}$, and $\mathrm{Thr}^{181}$, and PTI-125 significantly reduced phosphorylation at all three sites. Levels of tau protein phosphorylated at each site were measured in the immunoprecipitates of an anti-tau antibody that did not distinguish its phosphorylation state by Western blotting with specific antibodies separately recognizing each tau phosphoepitope. Blots (inset) were analyzed by densitometric quantitation. $n=7$ or $8 .{ }^{*} p<0.01$ vs sham, vehicle; $\# p<0.01$ vs $A \beta_{42}$, vehicle.

nicotine, PNU282987, $\alpha$-bungarotoxin, methyllycaconitine, galantamine, memantine, and $\mathrm{A} \beta_{40}$ along with $0.1 \mu \mathrm{M} \mathrm{A} \beta_{42}$. Incubation continued for $1 \mathrm{~h}$ in the dark. The incubation mixture in a total incubation volume of $0.5 \mathrm{ml}$ was aerated for 1 min every 15 min with $95 \% \mathrm{O}_{2} / 5 \% \mathrm{CO}_{2}$. Reaction was terminated by the addition of $1.5 \mathrm{ml}$ of ice-cold $\mathrm{Ca}^{2+}$-free $\mathrm{K}-\mathrm{R}$, and slices were collected by a brief centrifugation.

Assessment of FLNA- $\alpha 7 n A C h R$, FLNA-TLR4, and $A \beta_{42}-\alpha 7 n A C h R$ associations by coimmunoprecipitation. These assessments used previously described coimmunoprecipitation methods (Wang et al., 2009). Two hundred micrograms of synaptosomes from either postmortem brain slices or prefrontal cortex or hippocampus of treated mice were pelleted by centrifugation, solubilized by brief sonication in $250 \mu \mathrm{l}$ of immunoprecipitation buffer (containing, in mm: 25 HEPES, pH 7.5, $200 \mathrm{NaCl}, 1$ EDTA, 50 $\mu \mathrm{g} / \mathrm{ml}$ leupeptin, $10 \mu \mathrm{g} / \mathrm{ml}$ aprotinin, $2 \mu \mathrm{g} / \mathrm{ml}$ soybean trypsin inhibitor, 0.04 PMSF, $5 \mathrm{NaF}, 1$ sodium vanadate, $0.5 \beta$-glycerophosphate, and $0.1 \%$ 2 -mercaptoethanol containing $0.5 \%$ digitonin, $0.2 \%$ sodium cholate, and $0.5 \% \mathrm{NP}-40$ ) and incubated at $4^{\circ} \mathrm{C}$ with end-to-end shaking for $1 \mathrm{~h}$. After dilution with $750 \mu \mathrm{l}$ of ice-cold immunoprecipitation buffer and centrifugation $\left(4^{\circ} \mathrm{C}\right)$ to remove insoluble debris, the FLNA $-\alpha 7 n A C h R / T L R 4$ and $\mathrm{A} \beta_{42}-\alpha 7 \mathrm{nAChR}$ complexes in the lysate were isolated by immunoprecipitation with $16 \mathrm{~h}$ incubation at $4^{\circ} \mathrm{C}$ with respective rabbit anti-FLNA $(1 \mu \mathrm{g})$ and anti-A $\beta_{42}$ antibodies $(1 \mu \mathrm{g})$ immobilized on protein A-conjugated agarose beads. The resultant immunocomplexes were pelleted by centrifugation at $4^{\circ} \mathrm{C}$. After three washes with $1 \mathrm{ml}$ of ice-cold PBS, $\mathrm{pH} 7.2$, and centrifugation, the isolated FLNA $-\alpha 7 \mathrm{nAChR} / \mathrm{TLR} 4$ and $\mathrm{A} \beta_{42}-\alpha 7 \mathrm{nAChR}$ complexes were solubilized by boiling for $5 \mathrm{~min}$ in $100 \mu \mathrm{l}$ of SDS-PAGE sample preparation buffer $(62.5 \mathrm{~mm}$ Tris- $\mathrm{HCl}, \mathrm{pH}$ 6.8, 10\% glycerol, 2\% SDS, 5\% 2-mercaptoethanol, $0.1 \%$ bromophenol blue). The content of $\alpha 7 \mathrm{nAChRs} /$ TLR 4 s in $50 \%$ of the anti-FLNA and $\alpha 7 \mathrm{nAChRs}$ in $50 \%$ of the anti-A $\beta_{42}$ immunoprecipitate was determined by Western blotting with monoclonal anti- $\alpha 7 \mathrm{nAChR}$ or -TLR4 antibodies. To affirm the effect of PTI-125 on $\alpha 7 \mathrm{nAChR}$-/TLR4-FLNA linkages, lysates from $200 \mu \mathrm{g}$ of solubilized synaptosomes derived from control FCX slices incubated with vehicle and $0.1 \mu \mathrm{M}$
$\mathrm{A} \beta_{42}$ as well as $\mathrm{AD} \mathrm{FCX}$ slices incubated with vehicle and $1 \mathrm{~nm}$ PTI- 125 were assessed by a two-step immunoprecipitation. Lysates were immunoprecipitated first with $1 \mu \mathrm{g}$ of anti- $\alpha 7 \mathrm{nAChR}$ to obtain the $\alpha 7 \mathrm{nAChR-FLNA} \mathrm{com-}$ plexes. The resultant supernatants were then immunoprecipitated with $1 \mu \mathrm{g}$ of anti-TLR4 to obtain TLR4-FLNA complexes. In addition, lysates from $\alpha 7 \mathrm{nAChR}$ agent-incubated control tissues were immunoprecipitated with anti- $\alpha 7 \mathrm{nAChR}$ to obtain $\alpha 7 \mathrm{nAChR}$-FLNA complexes. The FLNA$\alpha 7 \mathrm{nAChR/TLR} 4$ complex blots were stripped and reprobed with monoclonal anti-FLNA, $-\alpha 7 \mathrm{nAChR}$, or -TLR4 to assess immunoprecipitation efficiency and loading. To determine $\mathrm{A} \beta_{42}-\alpha 7 \mathrm{nAChR}$ complex levels, immobilized rabbit anti-actin $(0.5 \mu \mathrm{g})$-protein A-conjugated agarose was added together with anti-A $\beta_{42}$ in the coimmunoprecipitation process. The content of $\beta$-actin in resultant immunoprecipitates was analyzed by immunoblotting using monoclonal anti- $\beta$-actin to illustrate even immunoprecipitation efficiency and loading.

Tau phosphorylation. Using an established method (Wang et al., 2003, 2010), tau proteins in synaptosomes from ICV A $\beta_{42}$-infused mice were immunoprecipitated with immobilized anti-tau (SC-65865), which does not discriminate between phosphorylation states. The levels of phosphorylated tau (pSer ${ }^{202}$ tau, pThr ${ }^{231}$ tau and $\mathrm{pThr}^{181}$ tau) and total tau precipitated (loading controls) were assessed by Western blotting using antibodies specific to each individual phosphoepitope and the anti-tau, respectively.

Assessment of $\mathrm{Ca}^{2+}$ influx as indices of $\alpha 7 n A C h R$ and NMDAR function and cell death. The effect of PTI- 125 on $\mathrm{Ca}^{2+}$ influx after stimulation of $\alpha 7 \mathrm{nAChR}$ or NMDAR was assessed in treated mice or postmortem FCX. Because the level of voltage-gated $\mathrm{Ca}^{2+}$ channel activity indicates the integrity of the cells, $\mathrm{K}^{+}$-depolarization mediated $\mathrm{Ca}^{2+}$ influx was used to assess the effect of PTI-125 on $\mathrm{A} \beta_{42}$-induced cell death, dysfunction, or both in treated mice and in postmortem tissues. As described previously (Wang et al., 2010), brain synaptosomes $(50-100 \mu \mathrm{g})$ were incubated at $37^{\circ} \mathrm{C}$ for $5 \mathrm{~min}$ in oxygenated $1.2 \mathrm{~mm}\left(\alpha 7 \mathrm{nAChR}\right.$ and $\left.\mathrm{K}^{+}\right)$or 0.3 $\mathrm{mM} \mathrm{Mg}^{2+}$ containing K-R (low $\mathrm{Mg}^{2+} \mathrm{K}-\mathrm{R}$ [LMKR] for NMDAR) con- 
taining $5 \mu \mathrm{M}{ }^{45} \mathrm{Ca}^{2+}(10 \mathrm{Ci} / \mathrm{mmol})$ followed by incubation with vehicle, $0.1-10 \mu \mathrm{M}$ PNU282987, a specific $\alpha 7 \mathrm{nAChR}$ agonist, or 0.1-10 $\mu \mathrm{M}$ NMDA $+1 \mu \mathrm{M}$ glycine for $5 \mathrm{~min}$ or $65 \mathrm{~mm} \mathrm{~K}^{+}$(made with isomolar replacement of $\mathrm{Na}^{+}$) for $1 \mathrm{~min}$ in a total incubation volume of $0.5 \mathrm{ml}$. The reaction was terminated by the addition of $0.5 \mathrm{ml}$ of ice-cold $\mathrm{Ca}^{2+}$-free K-R containing $0.5 \mathrm{~mm}$ EGTA and centrifugation at $4^{\circ} \mathrm{C}$. After two additional washes, ${ }^{45} \mathrm{Ca}^{2+}$ contents in synaptosomes were assessed using scintillation spectrometry (Beckman). Background ${ }^{45} \mathrm{Ca}^{2+}$ was estimated using hypotonically lysed synaptosomes. Absolute $\mathrm{Ca}^{2+}$ influx was calculated by subtracting background ${ }^{45} \mathrm{Ca}^{2+}$ count. The percentage increase in $\mathrm{Ca}^{2+}$ influx was calculated as percentage [(drugtreated - vehicle)/vehicle].

NMDAR and insulin receptor signaling assessments. NMDAR and insulin receptor (IR) signaling were assessed in LMKR (K-R) and PTI-125 (1 nM)-exposed postmortem FCX and in prefrontal cortex of treated mice. NMDAR activation and signaling were initiated by incubation of $\sim 10 \mathrm{mg}$ of in vitro treated brain slices with either LMKR (basal) or LMKR containing $10 \mu \mathrm{M}$ NMDA and $1 \mu \mathrm{M}$ glycine at $37^{\circ} \mathrm{C}$ for 30 min. For initiation of IR activation and signaling, $\sim 10 \mathrm{mg}$ slices were incubated with either $\mathrm{K}-\mathrm{R}$ (basal) or K-R containing $1 \mathrm{nM}$ insulin at $37^{\circ} \mathrm{C}$ for $30 \mathrm{~min}$. The incubation mixtures were aerated with $95 \% \mathrm{O}_{2} / 5 \% \mathrm{CO}_{2}$ every $10 \mathrm{~min}$ for $1 \mathrm{~min}$. Ligand stimulation was terminated by the addition of $1 \mathrm{ml}$ of ice-cold $\mathrm{Ca}^{2+}$-free $\mathrm{K}-\mathrm{R}$ containing $0.5 \mathrm{~mm}$ EGTA and $0.1 \mathrm{~mm}$ EDTA. Slices were harvested by brief centrifugation and homogenized in $0.25 \mathrm{ml}$ of ice-cold immunoprecipitation buffer. Homogenates were centrifuged at $1000 \times g$ for $5 \mathrm{~min}\left(4^{\circ} \mathrm{C}\right)$, and the supernatant (postmitochondrial fraction) was sonicated for $10 \mathrm{~s}$ on ice. Proteins were solubilized in $0.5 \%$ digitonin, $0.2 \%$ sodium cholate, and $0.5 \% \mathrm{NP}-40$ for $60 \mathrm{~min}$ at $4^{\circ} \mathrm{C}$ with end-over-end rotation. The resultant lysates were cleared by centrifugation at $50,000 \times g$ for $5 \mathrm{~min}$ and diluted with $0.75 \mathrm{ml}$ of immunoprecipitation buffer. Protein concentrations were measured by the Bradford method (Bio-Rad).

To determine NMDAR signaling and the NMDAR association with PSD95, the levels of NMDAR subunits, PSD-95, and NMDAR-associated signaling molecules were measured in anti-NR1 immunoprecipitates. Brain slice lysates $(200 \mu \mathrm{g})$ were immunoprecipitated overnight at $4^{\circ} \mathrm{C}$ with $2 \mu \mathrm{g}$ of immobilized anti-NR1 onto covalently conjugated protein A-agarose beads (Pierce-Endogen). Anti-NR1 immunoprecipitates were incubated with 75 $\mu l$ of antigen elution buffer (Pierce-Endogen) and 2\% SDS for 2 min on ice, centrifuged to remove antibody-protein A-agarose complexes, and neutralized immediately with $10 \mu \mathrm{l}$ of $1.5 \mathrm{M}$ Tris buffer, $\mathrm{pH} 8.8$, followed by the addition of $65 \mu$ l of $2 \times$ PAGE sample buffer and boiling for $5 \mathrm{~min}$. Seventyfive microliters of the obtained eluates $(50 \%)$ were then size fractionated on $7.5 \%$ SDS-PAGE. Proteins were transferred to nitrocellulose membrane, and the levels of various NMDAR subunits, PSD-95, and signaling proteins were measured using Western blotting with antibodies for NR1, PSD-95, nNOS, phospholipase C- $\gamma 1, \gamma \mathrm{PKC}, \mathrm{pY}^{402} \mathrm{PyK} 2, \mathrm{pY}^{416} \mathrm{Src}$, or phosphotyrosine. Blots were stripped and reprobed with anti-NR1 to assess loading.

To determine IR activation and signaling, the levels of $\mathrm{pY}^{1150 / 1151}$ - and $\mathrm{pY}^{960}$-IRs as well as insulin receptor substrate (IRS)-1 recruited to IR were measured in anti-IR $\beta$ immunoprecipitates after incubation of brain slices with $1 \mathrm{nM}$ insulin in K-R. These experiments followed the above procedures for assessing NMDAR signaling but were immunoprecipitated with immobilized anti-IR $\beta$-protein A-agarose beads and detected levels of activated IR $\left(\mathrm{pY}^{1150 / 1151}\right.$ and $\left.\mathrm{pY}^{960}\right)$ and recruited IRS-1 using Western blotting with antibodies for $\mathrm{pY}^{1150 / 1151}$-IR $\beta, \mathrm{pY}^{972}$-IR $\beta$, or IRS-1. Blots were stripped and reprobed with anti-IR $\beta$ to assess the loading.
Table 1. Effects of $\alpha 7 \mathrm{nAChR}$ agents on FLNA recruitment to $\alpha 7 \mathrm{nAChR}$

\begin{tabular}{|c|c|c|c|c|}
\hline Agent & $\begin{array}{l}\mathrm{FLNA} / \alpha 7 \mathrm{nAChR} \text { ratio } \\
\text { (stimulation vs vehicle, } \% \text { ) }\end{array}$ & $\begin{array}{l}\text { Statistics vs } \\
\text { vehicle, } p\end{array}$ & $\begin{array}{l}\text { A } \beta 42 \\
\text { effect, } \%\end{array}$ & $\begin{array}{l}\text { Statistics vs } \\
A \beta 42, p\end{array}$ \\
\hline Vehicle & $0.07 \pm 0.01$ & & & \\
\hline $0.1 \mu \mathrm{M} A \beta 42$ & $0.73 \pm 0.05(1012.3 \pm 104.9)$ & $<0.0001$ & 100 & \\
\hline $1 \mu \mathrm{MA} \beta 40$ & $0.28 \pm 0.03(341.9 \pm 65.1)$ & 0.001 & $34.8 \pm 6.6$ & $<0.001$ \\
\hline $1 \mu \mathrm{m}$ Nicotine & $0.13 \pm 0.02(107.7 \pm 31.4)$ & $<0.001$ & $11.0 \pm 3.2$ & 0.001 \\
\hline $1 \mu \mathrm{M}$ PNU282987 & $0.12 \pm 0.02(87.1 \pm 37.9)$ & 0.01 & $8.9 \pm 3.9$ & 0.001 \\
\hline $1 \mu \mathrm{M} \alpha$-Bungarotoxin & $0.07 \pm 0.01(7.5 \pm 6.6)$ & 0.65 & $0.8 \pm 0.7$ & $<0.001$ \\
\hline $1 \mu \mathrm{m}$ Methyllycaconitine & $0.08 \pm 0.02(19.8 \pm 12.2)$ & 0.21 & $2.0 \pm 1.2$ & $<0.001$ \\
\hline $1 \mu \mathrm{m}$ Galantamine & $0.08 \pm 0.02(17.1 \pm 14.6)$ & 0.37 & $1.7 \pm 1.5$ & $<0.001$ \\
\hline $1 \mu \mathrm{m}$ Memantine & $0.21 \pm 0.03(225.9 \pm 38.5)$ & $<0.00001$ & $23.0 \pm 3.9$ & 0.001 \\
\hline
\end{tabular}

Assessment of cytokine levels in ICV A $\beta_{42}$-infused mice. Parietal cortices $(\sim 10 \mathrm{mg})$ from vehicle-treated sham, PTI-125-treated sham, vehicletreated ICV A $\beta_{42}$, and PTI-125-treated ICV A $\beta_{42}$ mice were first thawed slowly $\left(-80^{\circ} \mathrm{C}\right.$ to $-20^{\circ} \mathrm{C}$ to $\left.-4^{\circ} \mathrm{C}\right)$, homogenized in $100 \mu \mathrm{l}$ of ice-cold homogenization medium (25 mm HEPES, pH 7.5, $50 \mathrm{~mm} \mathrm{NaCl}$, mixture of protease and protein phosphatase inhibitors) by sonication, and then solubilized with $0.5 \% \mathrm{NP}-40,0.2 \% \mathrm{Na}$ cholate, and $0.5 \%$ digitonin at $4^{\circ} \mathrm{C}$ for $1 \mathrm{~h}$ with end-over-end shaking. After centrifugation, the lysate was diluted with $500 \mu \mathrm{l}$ (total volume, $600 \mu \mathrm{l}$ ) and was used as the source of cytokines.

To determine the levels of cytokines, $0.5 \mu \mathrm{g} /$ well biotinylated mouse monoclonal anti-TNF- $\alpha$, -IL- 6 and -IL- $1 \beta$ were coated onto streptavidin-coated plates (Reacti-Bind NeutrAvidin High Binding Capacity Coated 96-well plate; Pierce-Endogen). Plates were washed three times with ice-cold $50 \mathrm{~mm}$ Tris $\mathrm{HCl}, \mathrm{pH} 7.4$, and incubated at $30^{\circ} \mathrm{C}$ with $100 \mu \mathrm{l}$ of lysate derived as described above for $1 \mathrm{~h}$. Plates were washed three times with ice-cold $50 \mathrm{~mm}$ Tris $\mathrm{HCl}, \mathrm{pH} 7.4$, and incubated at $30^{\circ} \mathrm{C}$ with $0.5 \mu \mathrm{g} /$ well unconjugated rabbit anti-TNF- $\alpha$, anti-IL- 6 , and antiIL- $1 \beta$ for $1 \mathrm{~h}$. After two washes with $50 \mathrm{~mm}$ Tris $\mathrm{HCl}, \mathrm{pH}$ 7.4, each well was incubated in $0.5 \mu \mathrm{g} /$ well FITC-conjugated anti-rabbit IgG (human and 

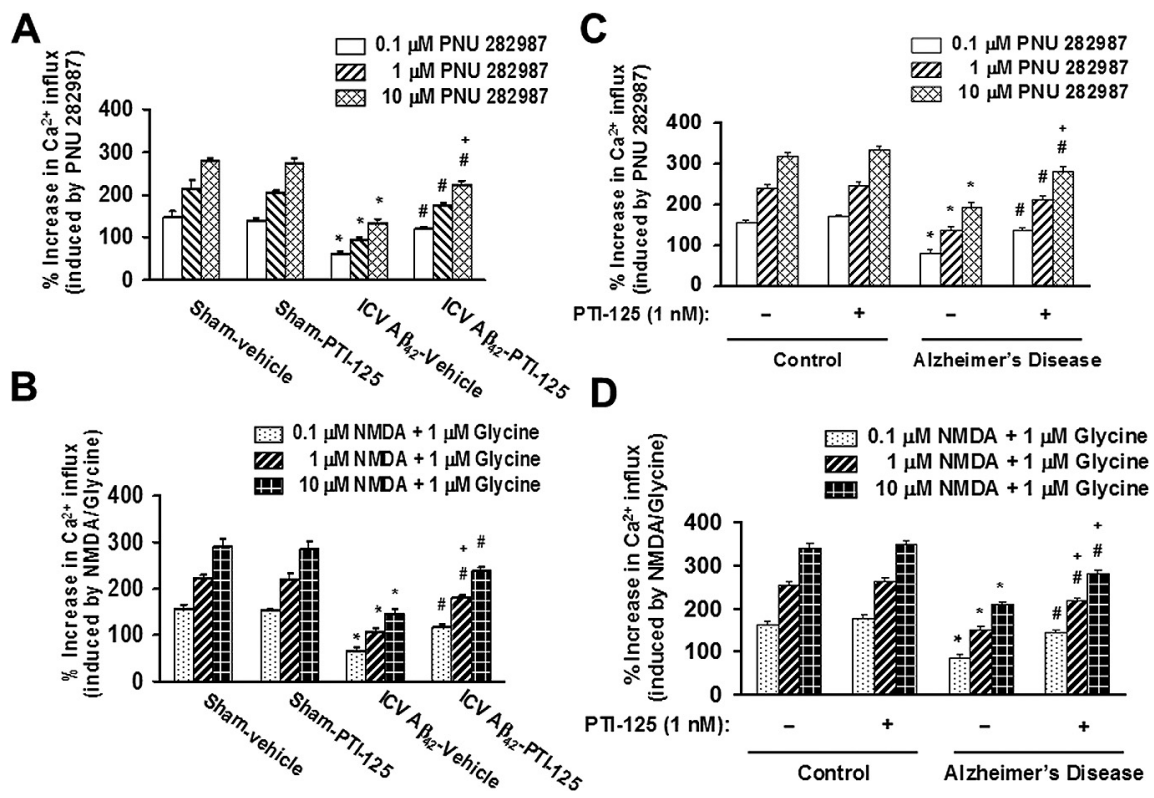

Figure 3. PTI-125 treatment of ICV A $\beta_{42}$-infused mice normalized the $A \beta_{42}$-induced $\alpha 7 n A C h R(A)$ and NMDAR (B) dysfunction, realized by reduced calcium influx in response to varying doses of the full $\alpha 7 \mathrm{nAChR}$ agonist PNU282987 and by the NMDAR co-agonists NMDA and glycine. $n=7$ or $8 .{ }^{*} p<0.01$ vs sham, vehicle; ${ }^{\#} p<0.01$ vs $A \beta_{42}$, vehicle; ${ }^{+} p<0.01$ vs vehicle-treated and PTI-125-treated sham groups. Similarly, 1 h incubation with PTI-125 of postmortem AD or $A \beta_{42}$-treated control tissue restored $\alpha 7 \mathrm{nAChR}(\boldsymbol{C})$ and NMDAR (D) function. $n=11 .{ }^{*} p<0.01$ vs vehicle-treated control; ${ }^{*} p<0.01$ vs vehicle-treated AD group; ${ }^{+} p<0.01$ vs vehicle-treated and PTI-125-treated control groups.
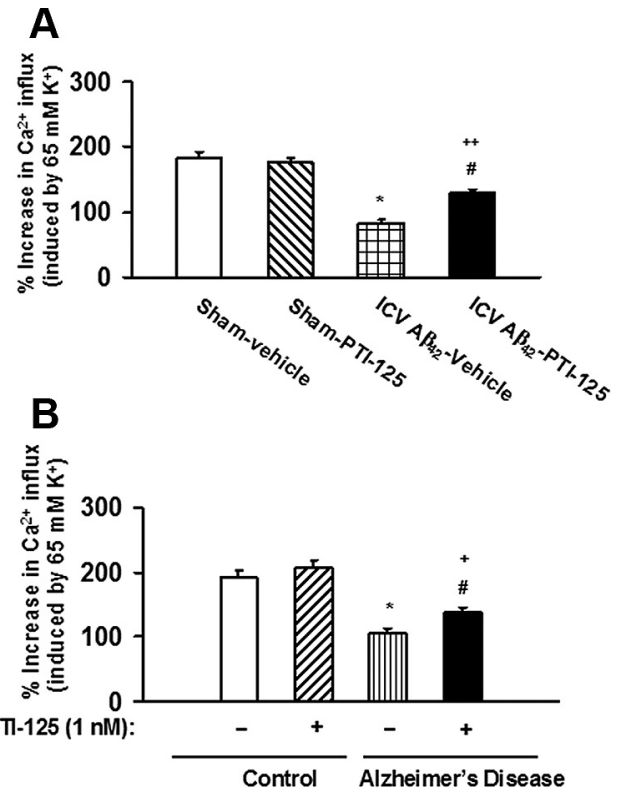

Figure 4. $\quad A, A \beta_{42}$ reduced $\mathrm{K}^{+}$-evoked $\mathrm{Ca}^{+2}$ influx, indicating dead, dying, or dysfunctional cells, and PTI-125 attenuated this $A \beta_{42}$-induced deleterious effect. $n=7$ or $8 .{ }^{*} p<0.01$ vs sham, vehicle; ${ }^{\#} p<0.01$ vs $A \beta_{42}$, vehicle; ${ }^{++} p<0.05$ vs vehicle-treated and PTI-125treated sham groups. $\boldsymbol{B}$, Similarly, PTI- 125 incubation partially normalized the drastic reduction in depolarization-induced calcium influx in postmortem $A D$ or $A \beta_{42}$-treated control tissue. $n=$ 11. ${ }^{*} p<0.01$ vs vehicle-treated control; ${ }^{*} p<0.01$ vs vehicle-treated $A D$ group; ${ }^{+} p<0.01$ vs vehicle-treated and PTI-125-treated control groups.

mouse absorbed) for $1 \mathrm{~h}$ at $30^{\circ} \mathrm{C}$. Plates were washed twice with $200 \mu \mathrm{l}$ of ice-cold Tris $\mathrm{HCl}$, and the residual FITC signals were determined by a multimode plate reader (DTX880; Beckman). Each lysate was surveyed twice.

Immunohistochemical studies of ICV A $\beta_{42}$-infused mice. Quantitative immunohistochemistry on consecutive $5 \mu \mathrm{m}$ sections containing prefrontal cortex and entorhinal cortex/hippocampus was used to deter- mine the levels of $\mathrm{A} \beta_{42}$ aggregates/plaques and neurofibrillary pathology (NFT and paired helical filament $[\mathrm{PHF}]$ immunoreactivity) using single-labeling immunohistochemistry, as described previously (D’Andrea et al., 2001; Nagele et al., 2002; Wang et al., 2010). One section was immunostained with anti-NFT or anti-PHF. The next (consecutive) section (often containing the same neuron) was immunostained with anti- $\mathrm{A} \beta_{42}$ antibodies to measure relative levels of accumulated $\mathrm{A} \beta_{42}$ peptide in neurons. The relative $\mathrm{A} \beta_{42}$ accumulation was compared among different cell types using computer-assisted image analysis, as described previously (Wang et al., 2000b). Brain tissues were fixed at $4^{\circ} \mathrm{C}$ in $0.15 \mathrm{M}$ phosphate-buffered

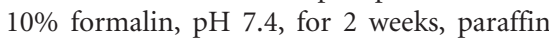
embedded, serially sectioned at $5 \mu \mathrm{m}$, and processed for bright-field microscopy. $\mathrm{A} \beta_{42}$ immunoreactivity was absent when preabsorbing anti- $\mathrm{A} \beta_{42}$ with $\mathrm{A} \beta_{42}$ but not $\mathrm{A} \beta_{42-1}$. Specimens were examined using a Nikon FXA microscope with a Princeton Instruments CCD camera and were recorded digitally. Relative intensities of the NFT/PHF and $\mathrm{A} \beta_{42}$ immunoreactivity were measured and compared among similar and different cell types using Image Pro Plus (Media Cybernetics) and MetaMorph (Molecular Devices) software. The correlations between the amount of NFT/PHF immunoreactivity and $\mathrm{A} \beta_{42}$-positive accumulation within mature neurons were also determined.

Assessment of PTI-125 effects on $A \beta_{42}$ affinity for $\alpha 7 n A C h R s$. To determine the effect of PTI- 125 on A $\beta_{42}$ affinity for the surface $\alpha 7 \mathrm{nAChRs}$, synaptosomes $(200 \mu \mathrm{g})$ prepared from postmortem FCX from control subjects or SK-N-MC cells (human neuroblastoma cell line from American Type Culture Collection) were biotinylated using a biotinylation kit (ThermoFisher Scientific). The biotinylated synaptosomes/cells were lysed by brief sonication in hypertonic solution and were used as the tissue source to determine $\mathrm{A} \beta_{42}$ affinity for the $\alpha 7 \mathrm{nAChRs}$ in the presence and absence of 1 nM PTI-125.

Blocking PTI-125 effects with FLNA pentapeptide VAKGL. Synaptosomes prepared from postmortem FCX of control subjects were used to elucidate whether the pentapeptide FLNA fragment VAKGL functions as an FLNA decoy by binding to PTI-125, thereby blocking the PTI-125 effects and confirming this pentapeptide binding site on FLNA. Briefly, FCX synaptosomes $(200 \mu \mathrm{g})$ were incubated with oxygenated K-R containing $1 \mathrm{~nm}$ PTI-125 and $10 \mu \mathrm{M}$ VAKGL or alanine-substituted VAAGL (a control pentapeptide that does not bind PTI-125) alone or together with $0.1 \mu \mathrm{M} \mathrm{A} \beta_{42}$ at $37^{\circ} \mathrm{C}$ for $30 \mathrm{~min}$. Synaptosomes were harvested by centrifugation and solubilized, and lysates were immunoprecipitated with anti-FLNA or anti-tau. The $\alpha 7 \mathrm{nAChR}$ and TLR4 contents in the anti-FLNA immunoprecipitates, as well as $\mathrm{pS}^{202}, \mathrm{pT}^{181}$, and $\mathrm{pT}^{231}$ tau levels in the anti-tau immunoprecipitates, were determined by Western blotting. Blots were stripped and reprobed with anti-FLNA and anti-tau, respectively, to ascertain even immunoprecipitation and loading.

Lymphocyte treatment and assessments of FLNA- $\alpha 7 n A C h R / T L R 4$ and $\alpha 7 n A C h R-A \beta_{42}$ complex levels. To prepare lymphocytes, $7 \mathrm{ml}$ of venous blood was collected into an EDTA-containing collecting tube or S-monovette (Sarstedt). Collected blood $(6 \mathrm{ml})$ was layered onto $6 \mathrm{ml}$ of Histopaque-1077 (Sigma) at $25^{\circ} \mathrm{C}$, and the anticoagulated blood was centrifuged at $400 \times g$ for $30 \mathrm{~min}\left(25^{\circ} \mathrm{C}\right)$ to yield plasma (top layer) and lymphocytes (opaque interface). The lymphocytes were washed twice by mixing with $6 \mathrm{ml}$ of oxygenated K-R followed by centrifugation at $250 \times$ $g$ for $10 \mathrm{~min}$ and resuspension. The final pellet was resuspended in $250 \mu \mathrm{l}$ of oxygenated K-R before protein content determination by the Bradford method and assessment of the levels of FLNA- $\alpha 7$ nAChR/TLR4 and $\mathrm{A} \beta_{42}-\alpha 7 \mathrm{nAChR}$ complexes. To store lymphocytes, the lymphocyte pel- 
let was resuspended in $250 \mu \mathrm{l}$ of ice-cold oxygenated K-R containing 10\% glycerol and was stored at $-20^{\circ} \mathrm{C}$ for $1 \mathrm{~h}$ before storage at $-80^{\circ} \mathrm{C}$.

To determine the levels of FLNA$\alpha 7 \mathrm{nAChR} / \mathrm{TLR} 4$ and $\mathrm{A} \beta_{42}-\alpha 7 \mathrm{nAChR}$ complexes in the lymphocytes, lymphocytes (100 $\mu \mathrm{g})$ from control subjects were incubated for $30 \mathrm{~min}$ at $37^{\circ} \mathrm{C}$ in $0.25 \mathrm{ml}$ of $\mathrm{K}-\mathrm{R}$ without or with $100 \mathrm{~nm} \mathrm{~A} \beta_{42}$, and lymphocytes $(50 \mu \mathrm{g})$ from $\mathrm{AD}$ subjects were incubated for $30 \mathrm{~min}$ at $37^{\circ} \mathrm{C}$ in $0.25 \mathrm{ml}$ of $\mathrm{K}-\mathrm{R}$. Lymphocytes from control and $\mathrm{AD}$ subjects were also simultaneously incubated with or without PTI-125 (1 $\mathrm{nM})$. The incubation mixture was aerated with $95 \% \mathrm{O}_{2} / 5 \% \mathrm{CO}_{2}$ every $10 \mathrm{~min}$ for $1 \mathrm{~min}$ during the incubation. If frozen lymphocyte samples were used, lymphocyte suspension was gradually thawed by storing at $-20^{\circ} \mathrm{C}$ for $1 \mathrm{~h}$ after removal from $-80^{\circ} \mathrm{C}$ and then thawed at $4^{\circ} \mathrm{C}$.

Incubation was terminated by adding $1 \mathrm{ml}$ of ice-cold $\mathrm{Ca}^{2+}$-free $\mathrm{K}$ - $\mathrm{R}$ containing $0.5 \mathrm{~mm}$ EGTA/0.1 mм EDTA, protease, and phosphatase inhibitors followed by centrifugation. The resultant lymphocyte pellet was homogenized in $0.25 \mathrm{ml}$ of ice-cold immunoprecipitation buffer. Homogenates were centrifuged at $1000 \times g$ for $5 \mathrm{~min}\left(4^{\circ} \mathrm{C}\right)$, and the supernatant (post-mitochondrial fraction) was sonicated for $10 \mathrm{~s}$ on ice and solubilized in $0.5 \%$ digitonin $/ 0.2 \%$ sodium cholate $/ 0.5 \% \mathrm{NP}-40$ for $60 \mathrm{~min}\left(4^{\circ} \mathrm{C}\right)$ with end-to-end rotation. Resultant lysates were cleared by centrifugation at $50,000 \times g$ for 5 min and diluted with $0.75 \mathrm{ml}$ of immunoprecipitation buffer before coimmunoprecipitation to assess FLNA $-\alpha 7$ nAChR/TLR4 and $\mathrm{A} \beta_{42}-\alpha 7 \mathrm{nAChR}$ complexes.

Western blot analysis. Solubilized immunoprecipitates derived from coimmunoprecipitation assays were separated by either 7.5 or $10 \%$ SDS-PAGE and electrophoretically transferred to nitrocellulose membranes. Membranes were washed with PBS and blocked overnight at $4^{\circ} \mathrm{C}$ with $10 \%$ milk in PBS with $0.1 \%$ Tween-20 (PBST). After three 5 min washes with $0.1 \%$ PBST, the membranes were incubated at room temperature for $2 \mathrm{~h}$ with the appropriate antibody at 1:500-1:1000 dilutions. After three 2 min washes in 0.1\% PBST, membranes were incubated for $1 \mathrm{~h}$ with anti-species IgG-HRP (1:5000 dilution) and were washed with $0.1 \%$ PBST three times for 2 min each time. Immunoreactivity was visualized by reacting with chemiluminescent reagent (Pierce-Endogen) for exactly $5 \mathrm{~min}$ and immediate exposure to $\mathrm{x}$-ray film. Specific bands were quantified by densitometric scanning (GS-800 calibrated densitometer; Bio-Rad).

Statistical analysis. All data are presented as mean \pm SEM. Treatment/ group effects were evaluated by one-way ANOVA followed by NewmanKeul's multiple comparison. Two-tailed Student's $t$ test was also used as the post hoc test for between-group differences. The threshold for significance was $p<0.05$.

\section{Results}

FLNA recruitment required for $\alpha 7 \mathrm{nAChR}$ and tau phosphorylation

In an ICV $\mathrm{A} \beta_{42}$ infusion mouse model of $\mathrm{AD}, \mathrm{A} \beta_{42}$ dramatically increased FLNA association with both $\alpha 7 \mathrm{nAChR}$ and TLR4, caused tau phosphorylation at three phosphorylation sites of tau that are found in neurofibrillary tangles and impaired signaling of $\alpha 7$ nAChR, NMDARs, and IRs. Twice-daily treatment with 10 $\mathrm{mg} / \mathrm{kg}$ of PTI-125 markedly reduced these deleterious effects of the infused $\mathrm{A} \beta_{42}$. PTI-125 reduced $\mathrm{A} \beta_{42}$-induced increases in FLNA
WB

\section{NR1}

$-00-00-100$

nNOS

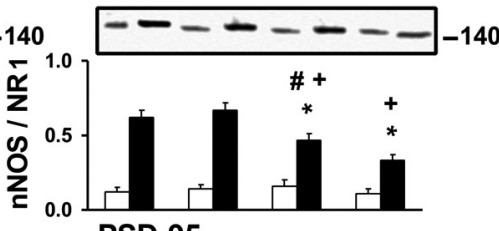

PSD-95
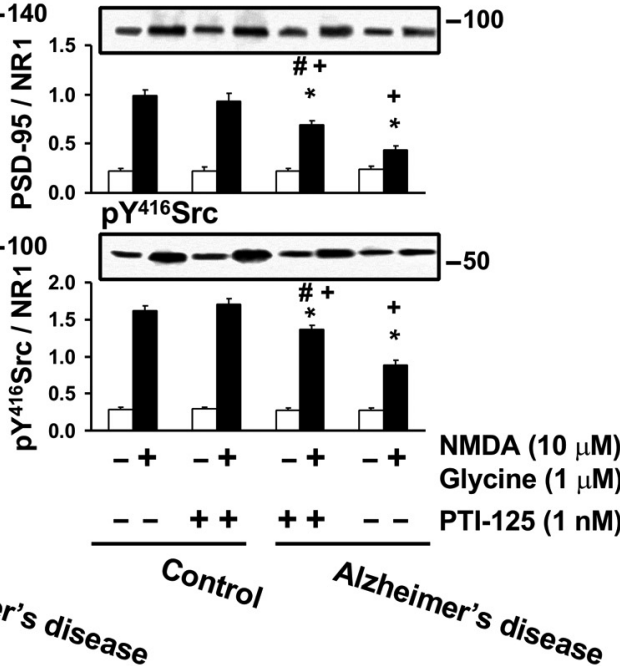

Glycine $(1 \mu \mathrm{M})$

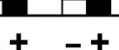

$\frac{++--}{4 / z h_{\text {eim }}}$

$-++++--$

disease

Figure 5. Incubation for $1 \mathrm{~h}$ with PTI-125 normalized NMDAR signaling impairment in postmortem AD brain slices and $A \beta_{42}$ treated control brain slices, evidenced by reductions in linkages of several signaling molecules to NR1, the obligatory NMDAR subunit. Western blots (inset) were analyzed by densitometric quantitation. $n=11 .{ }^{*} p<0.01$ vs vehicle-treated control group; ${ }^{\#} p<0.01$ vs vehicle-treated $A D$ group; ${ }^{+} p<0.01$ compared with PTI-125-treated control group.

associations with both $\alpha 7 \mathrm{nAChR}$ and TLR4 (Fig. $1 A, B$ ), suggesting a reduction in $\mathrm{A} \beta_{42}$-mediated signaling of both these receptors with corresponding suppression of the tau phosphorylation at all three phosphorylation sites (Fig. 1C). Essentially identical results were found by detecting FLNA in anti- $\alpha 7 \mathrm{nAChR}$ or anti-TLR4 immunoprecipitates (data not shown). FLNA association with $\alpha 7 \mathrm{nAChR}$ and TLR4 was also elevated in postmortem AD compared with control tissue, as evidenced by Western blot detection of $\alpha 7 \mathrm{nAChR}$ or TLR 4 in anti-FLNA immunoprecipitates as above (Fig. $2 A, B$, respectively) or by Western detection of FLNA in anti- $\alpha 7 \mathrm{nAChR}$ or anti-TLR4 immunoprecipitates (Fig. 2C,D). The fact that we can immunoprecipitate with anti- $\alpha 7 \mathrm{nAChR}$ and separately with anti-TLR4 in the same lysate and subsequently detect robust levels of FLNA in each suggests that these receptors are not sharing the same FLNA molecules. The addition of exogenous $\mathrm{A} \beta_{42}$ to control tissue elevated these associations, and PTI-125 incubation for $1 \mathrm{~h}$ reduced these associations in both $\mathrm{AD}$ and $\mathrm{A} \beta_{42}$-treated control tissue in this ex vivo setting.

$\mathrm{A} \beta_{42}$-induced FLNA recruitment to $\alpha 7 \mathrm{nAChRs}$ was mimicked by 10 -fold higher concentrations of $\mathrm{A} \beta_{40}$ or of the $\alpha 7$ nAChR agonists nicotine and PNU282987 with significantly lesser magnitudes. The $\alpha 7 \mathrm{nAChR}$ antagonists $\alpha$-bungarotoxin and methyllycaconitine and the cholinesterase inhibitor/positive allosteric nicotinic receptor modulator galantamine showed no effect (Table 1). Interestingly, memantine, an antagonist of both NMDAR and $\alpha 7 \mathrm{nAChR}$, elicited the recruitment of FLNA to $\alpha 7 \mathrm{nAChRs}$ with a magnitude not far from that of $\mathrm{A} \beta_{40}$. 

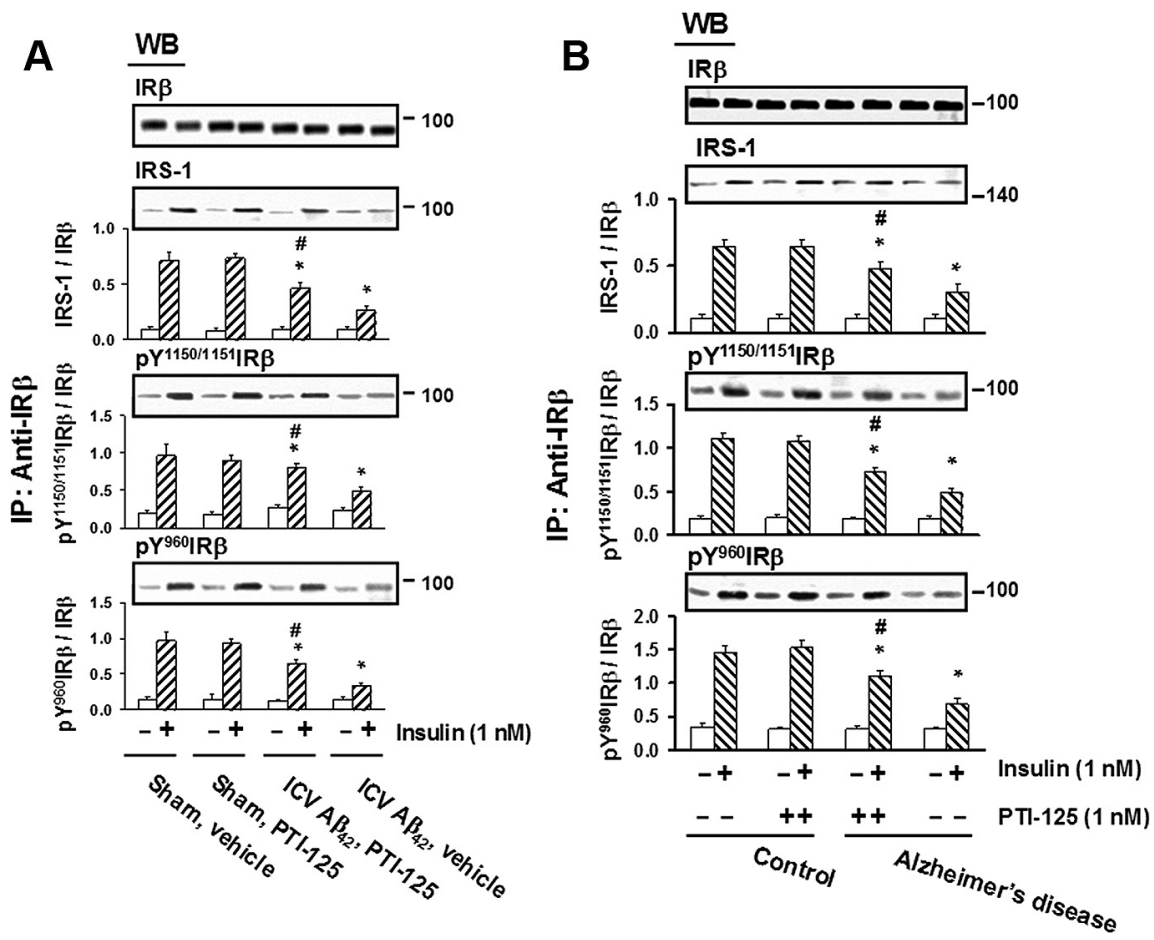

Figure 6. $A$, PTI-125 treatment ameliorated the $A \beta_{42}$-induced impairment in IR signaling in ICV A $\beta_{42}$-infused mice, as measured by the phosphorylation of IR $\beta$ and its association with the signaling adaptor molecule IRS-1. $n=7$ or $8 .{ }^{*} p<0.01$ vs sham, vehicle; ${ }^{\#} p<0.01$ vs $A \beta_{42}$, vehicle. $B$, Similarly, the deficit in IR signaling seen in postmortem $A D$ and $A \beta_{42}$-treated control brain slices was lessened by $1 \mathrm{~h}$ PTI-125 incubation. $n=11 .{ }^{*} p<0.01$ vs vehicle-treated control group; ${ }^{\#} p<0.01$ vs vehicle-treated AD group.

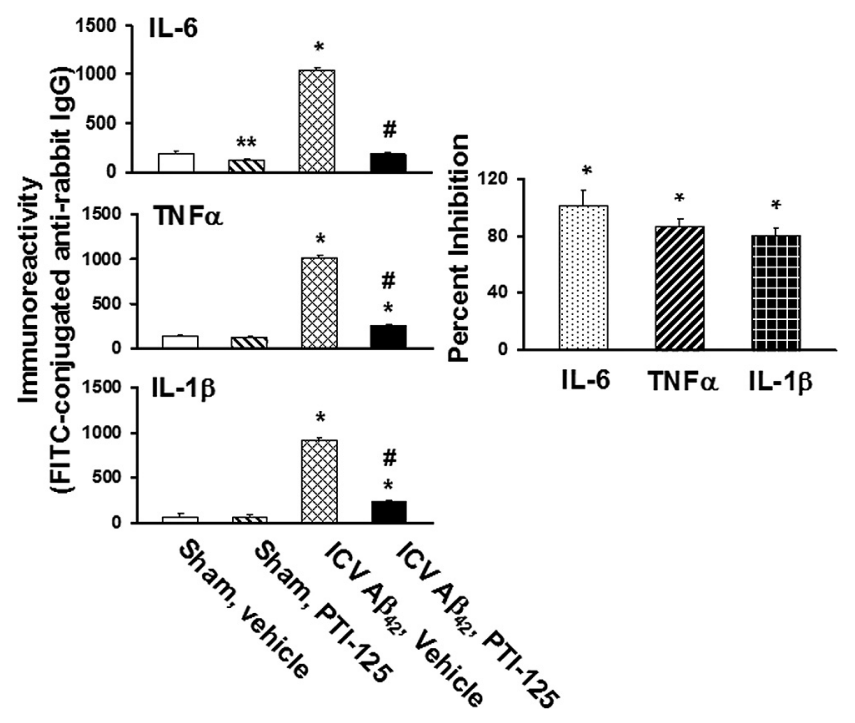

Figure 7. PTI-125 treatment of ICV $A \beta_{42}$-infused mice nearly abolished $A \beta_{42}$-induced production of inflammatory cytokines IL-6, TNF- $\alpha$, and IL-1 $\beta$ in parietal cortex, measured by a fluorescence ELISA assay. $n=7$ or $8 .{ }^{*} p<0.01$ vs respective cytokine level in sham, vehicle group; $\# p<0.01$ vs respective cytokine level in ICV A $\beta_{42}$, vehicle group.

PTI-125 normalizes $\alpha$ 7nAChR, NMDAR, and IR dysfunction The impact of PTI- 125 treatment on $\mathrm{A} \beta_{42}$-induced dysfunction was evaluated by agonist-evoked calcium influx through $\alpha 7 \mathrm{nAChRs}$ and NMDARs. In the sham-treated mice, PNU282987, an $\alpha 7 \mathrm{nAChR}$ full agonist, and NMDA/glycine elicited a dose-dependent increase in $\mathrm{Ca}^{2+}$ influx through $\alpha 7 \mathrm{nAChRs}$ and NMDARs, respectively. Agonist-induced $\alpha 7 \mathrm{nAChR}$ and NMDAR channel activation was greatly reduced in $\mathrm{A} \beta_{42}$-infused animals, and this impairment was normalized by PTI-125 (Fig. 3A, B). Similarly, $\alpha 7 \mathrm{nAChR}$ and NMDAR channel activation was impaired in $\mathrm{AD}$ tissue compared with that in age-matched control tissue, and PTI-125 significantly restored these deficits (Fig. $3 C, D)$.

Calcium influx after depolarization by $\mathrm{K}^{+}$, indicative of healthy cells, was used to assess overall cellular dysfunction or unhealthy cells. This $\mathrm{K}^{+}$-evoked calcium influx was reduced in both ICV $\mathrm{A} \beta_{42}$-infused mice and in $\mathrm{AD}$ compared with age-matched control tissue, demonstrating an elevated number of nonfunctioning cells. This depolarization-induced calcium influx was partially restored by PTI-125 incubation or PTI-125 treatment (Fig. 4).

That PTI-125 treatment can reverse NMDAR dysfunction is also evidenced by measuring NMDAR signaling. Both $\mathrm{A} \beta_{42}$-infused mice and $\mathrm{AD}$ postmortem tissue showed reductions in NMDA/ glycine-induced activation (phosphorylation) and in recruitment to NMDAR of six signaling components. Remarkably, $1 \mathrm{~h}$ incubation of $\mathrm{AD}$ brain slices with 1 nM PTI-125 normalized all six measures of this NMDAR signaling impairment without affecting the NMDAR subunit assemblies (Fig. 5). PTI125 treatment of ICV A $\beta_{42}$-infused mice produced virtually identical results (data not shown).

The effect of $\mathrm{A} \beta_{42}$ infusion on IR function was similarly assessed by the magnitude of insulin-induced tyrosine phosphorylation of IR $\beta$ and the level of insulin-induced IRS- 1 recruited to IRs. Both IR $\beta$ phosphorylation and IRS-1 recruitment were reduced by $\mathrm{A} \beta_{42}$ infusion and in $\mathrm{AD}$ tissue versus control tissue, and PTI-125 treatment or incubation significantly restored this signaling impairment (Fig. 6).

\section{PTI-125 reduces inflammatory cytokines}

Given that FLNA association with TLR4 is increased by $\mathrm{A} \beta_{42}$ and normalized by PTI-125, we assessed whether the levels of inflammatory cytokines are higher in ICV A $\beta_{42}$-infused brains and assessed the effect of PTI-125 treatment. ICV $\mathrm{A} \beta_{42}$ infusion increased IL- 6 , TNF- $\alpha$, and IL- $1 \beta$ production. PTI- 125 treatment completely abolished $\mathrm{A} \beta_{42}$-induced IL- 6 production and suppressed TNF- $\alpha$ and IL- $1 \beta$ levels by 86 and $80 \%$, respectively, illustrating a strong anti-inflammatory effect (Fig. 7).

\section{PTI-125 reduces $\mathrm{A} \boldsymbol{\beta}_{42}$ and pTau immunoreactivity}

Given that $\alpha 7 \mathrm{nAChRs}$ can mediate intraneuronal $\mathrm{A} \beta_{42}$ loading and $\mathrm{A} \beta_{42}$-induced tau phosphorylation, we assessed the levels of $\mathrm{A} \beta$ deposits and tau phosphorylation indicative of neurofibrillary lesions and NFTs in both FCX and hippocampus after ICV $\mathrm{A} \beta_{42}$ infusion and the effect of PTI-125 treatment by immunohistochemical method. $\mathrm{A} \beta_{42}$ infusion caused substantial pTau immunoreactivity that was markedly reduced by PTI- 125 treatment (Fig. $8 \mathrm{~A}$ ). Perhaps more striking was the abolition of amyloid deposits (A $\beta_{42}$ immunoreactivity) by PTI-125 (Fig. $8 B$ ), further supporting the theory that $\mathrm{A} \beta_{42}$ signaling by $\alpha 7 \mathrm{nAChR}$ 

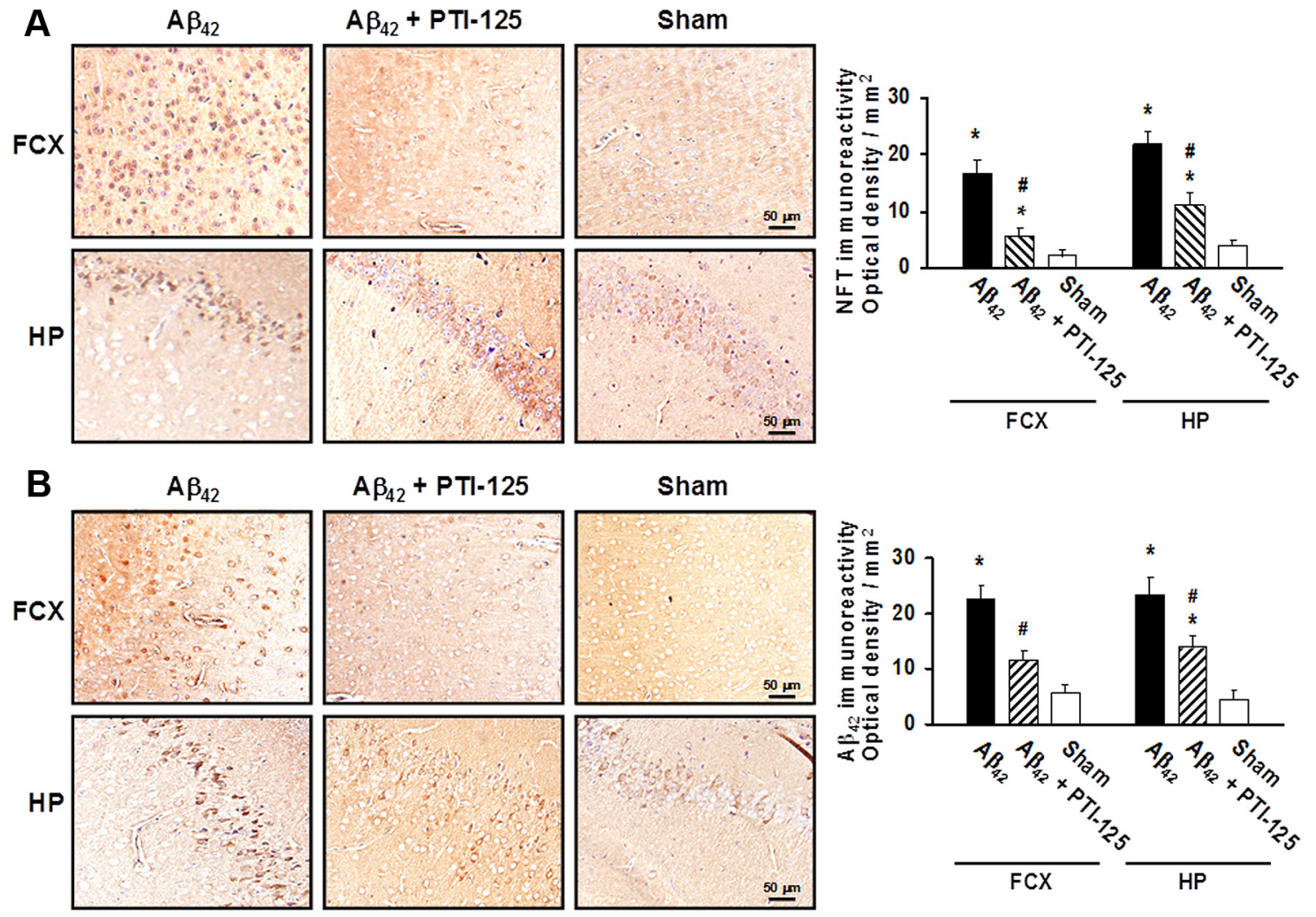

Figure 8. $A$, Representative sections immunostained with an anti-NFT (phospho-tau) antibody show that PTI-125 treatment dramatically reduced NFT immunoreactivity in both prefrontal cortex and hippocampus of mice receiving ICV $A \beta_{42}$ infusions. $B$, Representative sections immunostained for $A \beta_{42}$ aggregates show that PTI-125 treatment greatly reduced $A \beta_{42}$ deposits in both brain regions of $A \beta_{42}$-infused mice. Immunostaining was quantified by image analysis software. $n=7$ or 8 . ${ }^{*} p<0.01$ vs sham, vehicle; ${ }^{\#} p<0.01$ vs $A \beta_{42}$, vehicle.

also underlies the formation of $\mathrm{A} \beta$-containing plaques (Wang et al., 2009).

\section{PTI-125 reduces $\mathrm{A} \boldsymbol{\beta}_{42}$ affinity for $\alpha 7 \mathrm{nAChR}$}

In reducing the $\mathrm{A} \beta_{42}$-induced FLNA $-\alpha 7 \mathrm{nAChR}$ association, PTI-125 reduced the level of $\mathrm{A} \beta_{42}$ bound to $\alpha 7 \mathrm{nAChRs}$. In ICV $\mathrm{A} \beta_{42}$-infused mice, systemic PTI-125 treatment reduced the levels of $\mathrm{A} \beta_{42}-\alpha 7 \mathrm{nAChR}$ complexes by $60 \%$ in hippocampus and $75 \%$ in prefrontal cortex (data not shown). PTI-125 also significantly reduced the levels of $\mathrm{A} \beta_{42}-\alpha 7 \mathrm{nAChR}$ complexes in $\mathrm{AD}$ tissue, illustrating that substantial amounts of $\mathrm{A} \beta_{42}$ already bound to $\alpha 7 \mathrm{nAChRs}$ in late-stage $\mathrm{AD}$ tissue can be removed by PTI-125 binding to FLNA (Fig. 9A). A $\beta_{42}-\alpha 7 \mathrm{nAChR}$ complexes induced by $\mathrm{A} \beta_{42}$ treatment of age-matched control tissue were also reduced by PTI-125 (Fig. 9A). This removal of A $\beta_{42}$ from $\alpha 7 \mathrm{nAChR}$ by PTI-125 appears to occur because its binding to FLNA reduces the affinity of $\mathrm{A} \beta_{42}$ for $\alpha 7 \mathrm{nAChR}$ by 1000 -fold in postmortem control tissue (Fig. $9 B$ ) and by 10,000-fold in fresh SK-N-MC cells (Fig. 9C).

\section{Confirmation of FLNA binding as mechanism of action}

To affirm that the beneficial effect of PTI-125 rests on its specific binding to FLNA, we used a pentapeptide that is the sequence of the FLNA binding site (VAKGL) as a decoy. This pentapeptide prevents PTI-125 from binding FLNA in tissue and thereby prevents PTI-125 effects. In control postmortem tissue, the $\mathrm{A} \beta_{42^{-}}$ induced association of FLNA with both $\alpha 7 \mathrm{nAChR}$ and TLR 4 was blocked by PTI-125, but coincubation with the FLNA pentapeptide prevented PTI-125 blockade (Fig. 10). Similarly, the pentapeptide blocked PTI-125 suppression of tau phosphorylation in $\mathrm{A} \beta_{42}$-treated postmortem control tissue (Fig. 11). We used a pentapeptide with a midpoint alanine for lysine substitution (VAAGL) as an inactive control pentapeptide because it does not bind PTI-125.

\section{FLNA $-\alpha 7$ nAChR/TLR 4 and $A \boldsymbol{\beta}_{42}-\alpha 7$ nAChR associations are} increased in $\mathrm{AD}$ lymphocytes

Because lymphocytes contain $\alpha 7 \mathrm{nAChR}$ and TLR4, we assessed whether the associations of these receptors with FLNA are increased in the lymphocytes of AD patients and whether PTI-125 treatment ex vivo could disrupt these associations. We also tested the effect of PTI-125 on $\mathrm{A} \beta_{42}-\alpha 7 \mathrm{nAChR}$ complexes in AD lymphocytes and $\mathrm{A} \beta_{42}$-treated lymphocytes from age-matched control subjects. FLNA associations with $\alpha 7 \mathrm{nAChR}$ and with TLR4 were dramatically increased in $\mathrm{AD}$ and $\mathrm{A} \beta_{42}$-treated control lymphocytes compared with vehicle-treated control lymphocytes. Additionally, the level of $\mathrm{A} \beta_{42}-\alpha 7 \mathrm{nAChRcomplexes} \mathrm{was} \mathrm{elevated}$ in $\mathrm{AD}$ or $\mathrm{A} \beta_{42}$-treated control lymphocytes. Incubation with 1 nM PTI-125 for 30 min significantly reduced the increased associations with FLNA and the level of $\mathrm{A} \beta_{42}-\alpha 7 \mathrm{nAChR}$ complexes (Fig. 12).

\section{Discussion}

PTI-125 is a new chemical entity representing a novel approach to the prevention and treatment of AD. A molecule of $<300 \mathrm{Da}$, PTI-125 appears to be orally available and well tolerated because it produces notable plasma and CNS levels but negligible side effects at $2 \mathrm{~g} / \mathrm{kg}$ administered orally in rats. Although much $\mathrm{AD}$ research has focused on $\mathrm{A} \beta_{42}$ signaling through $\alpha 7 \mathrm{nAChR}$, the present study is the first to demonstrate that $A \beta_{42}$ signaling requires the recruitment of FLNA to $\alpha 7 \mathrm{nAChRs}$ : there is a profound increase in FLNA coupling to $\alpha 7 \mathrm{nAChR}$ in AD post- 


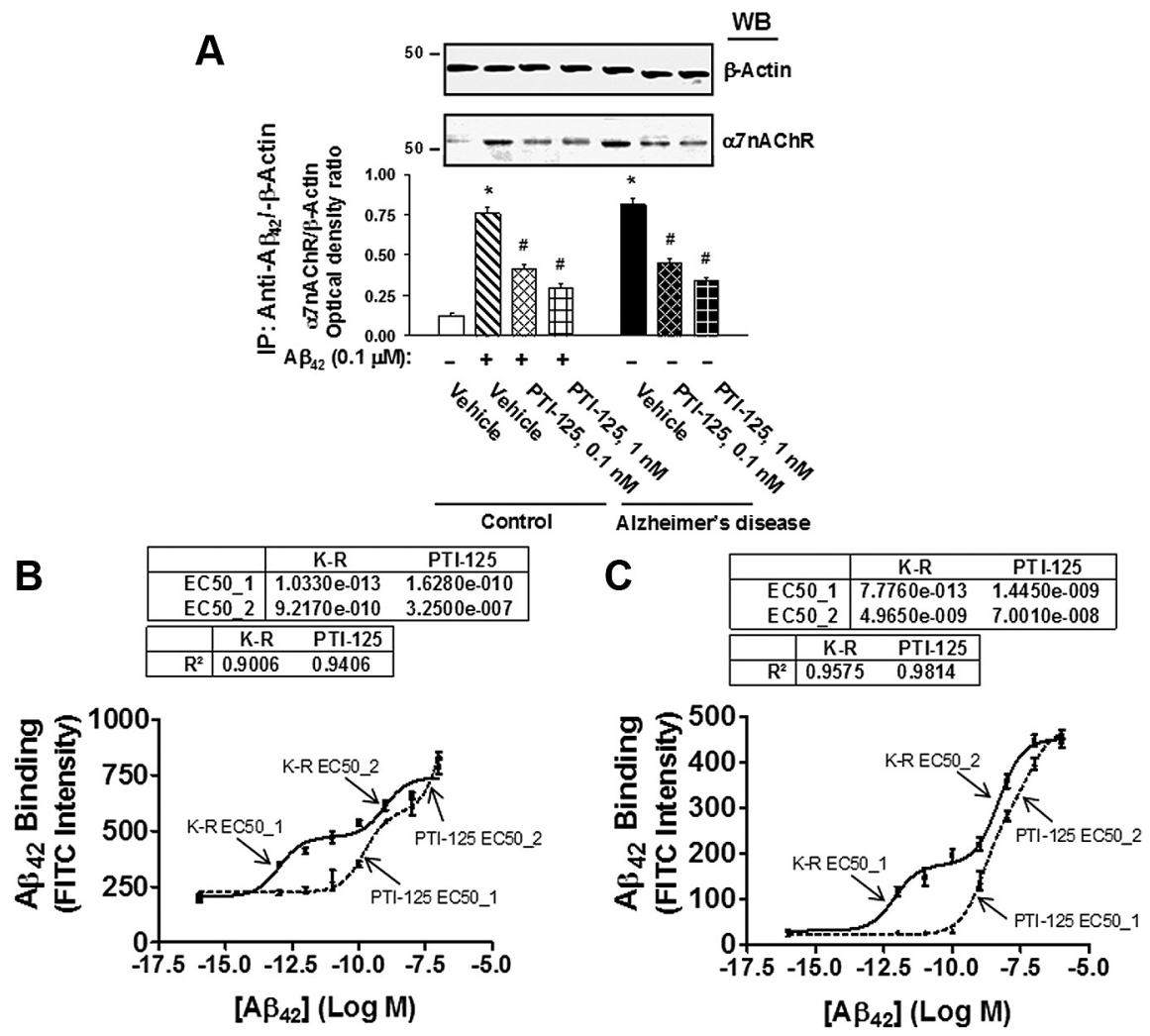

Figure 9. $A, A \beta_{42}-\alpha 7 n A C h R$ complexes were elevated in both $A \beta_{42}$-treated control tissue and AD tissue, and PTI- 125 incubation reduced this interaction in each. Blots (inset) of anti-A $\beta_{42}$ immunoprecipitates were probed with anti- $\alpha 7 \mathrm{nAChR}$ and analyzed by densitometric quantitation. $B$, PTI- 125 incubation reduced $A \beta_{42}$ binding affinity for $\alpha 7 \mathrm{nAChR} 1000$-fold from $100 \mathrm{fm}$ to $16 \mathrm{~nm}$ (dotted line) in biotinylated synaptic membranes from postmortem frontal cortices of controls without dementia. In the $\mathrm{K}-\mathrm{R}$ control condition (solid line), there were two binding sites, a high-affinity (EC50_1) and a lower-affinity (EC50_2) binding site, which were also reduced by PTI-125 incubation. C, In fresh SK-N-MC cells, PTI- 125 reduced this binding affinity 10,000-fold from $770 \mathrm{fm}$, the high-affinity binding site in the K-R control condition (solid line), to $1 \mathrm{~nm}$ (dotted line). $n=11$ for postmortem control tissue; $n=6$ for SK-N-MC cells. ${ }^{*} p<0.01$ vs vehicle-treated control; ${ }^{*} p<0.01$ vs $A \beta_{42}$-treated control or vehicle-treated AD.

A

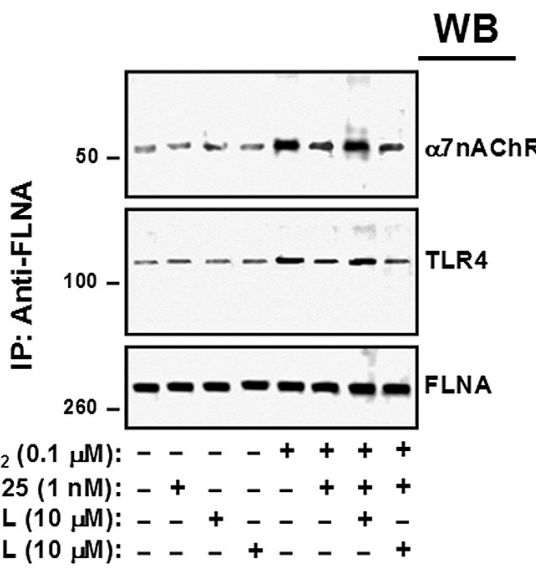

B
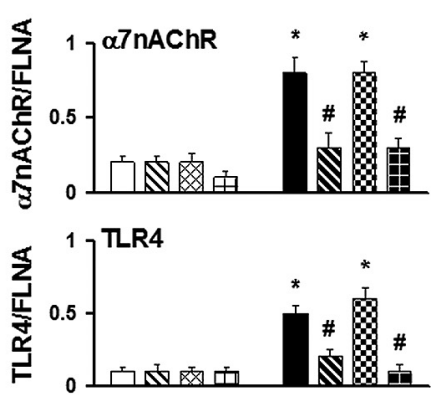

$\mathrm{A \beta}_{42}(0.1 \mu \mathrm{M}):-$ - $_{-}++++$

PTा-125 (1 nM): - + - - + + +

VAKGL $(10 \mu \mathrm{M}):-++-++$

$\operatorname{VAAGL}(10 \mu \mathrm{M}):-{ }_{-}+-\ldots+$

Figure 10. $\quad \boldsymbol{A}$, Acting as a decoy for the FLNA protein, the pentapeptide binding site of PTI-125 on FLNA (VAKGL) blocked the reduction by PTI- 125 in $A \beta_{42}$-induced FLNA $-\alpha 7 n A C h R / T L R 4$ association in postmortem frontal cortical synaptosomes. The inactive control pentapeptide (VAAGL) did not disrupt PTI- 125 reductions of these $A \beta_{42}$-induced FLNA associations. Western blots $(A)$ were analyzed by densitometric quantification $(\boldsymbol{B}) . n=3 .{ }^{*} p<0.01$ vs respective basal level; ${ }^{\#} p<0.01$ vs $A \beta_{42}$-exposed tissues.

mortem tissue or after $\mathrm{A} \beta_{42}$ exposure. Basal $\alpha 7 \mathrm{nAChR}$ associated FLNA levels are negligible. The model we propose is that the initial binding of $\mathrm{A} \beta_{42}$ to $\alpha 7 \mathrm{nAChR}$ recruits FLNA, which causes a conformational change in $\alpha 7 \mathrm{nAChR}$ that both enables the toxic signaling and increases $\mathrm{A} \beta_{42}$ affinity to $\alpha 7 \mathrm{nAChR}$. The fact that $\mathrm{A} \beta_{42}$ binding blocks $\mathrm{Ca}^{2+}$ influx by $\alpha 7 \mathrm{nAChRs}$ (Wang et al., 2009, 2010) suggests that one conformational change in $\alpha 7 \mathrm{nAChRs}$ may occur in the interface between extracellular and transmembrane domains, the area governing channel opening/desensitization (Bouzat et al., 2008). This conformational change likely exposes a positive charge-rich transmembrane region close to the $\mathrm{A} \beta_{42}$ binding site. FLNA binds this positive charge to stabilize the bound $\mathrm{A} \beta_{42}$ and additional binding of $\mathrm{A} \beta_{42}$ peptides, leading to eventual internalization of $\mathrm{A} \beta_{42}-\alpha 7 \mathrm{nAChR}$ complexes (Nagele et al., 2002). PTI-125 disruption of the FLNA $-\alpha 7 \mathrm{nAChR}$ interaction stops the pathological signaling and stops $\mathrm{A} \beta_{42}$ high-affinity anchoring to the receptor (Fig. 13). By binding FLNA instead of the receptor, PTI-125 blocks $\mathrm{A} \beta_{42}$ toxic signaling without disrupting $\alpha 7 \mathrm{nAChR}$ physiological activation by acetylcholine or altering its sensitivity or cell surface expression. PTI-125 efficacy in a mouse model and in human postmortem $\mathrm{AD}$ and $\mathrm{A} \beta_{42}$-treated control tissue on numerous $\mathrm{AD}$-related neuropathologies both validates the FLNA pentapeptide target and reinforces $\mathrm{A} \beta_{42}$ aberrant signaling by $\alpha 7 \mathrm{nAChR}$ as a predominant mechanism of $\mathrm{AD}$ pathology.

To assess the specificity of the $A \beta_{42^{-}}$ induced FLNA $-\alpha 7 \mathrm{nAChR}$ association, we examined $\mathrm{A} \beta_{40}, \alpha 7 \mathrm{nAChR}$ agonists and antagonists, and a cholinesterase/allosteric nicotinic receptor modulator by incubating postmortem control FCX slices with these agents at 10-fold higher concentrations. $\mathrm{A} \beta_{40}$, known to be less toxic than $\mathrm{A} \beta_{42}$ and to bind $\alpha 7 \mathrm{nAChR}$ with substantially lower affinity (Lee and Wang, 2003), also induced a notable FLNA $-\alpha 7 \mathrm{nAChR}$ association, though, at one-third the level induced by $\mathrm{A} \beta_{42}$, it was less robust. Agonists, but not antagonists, of $\alpha 7 \mathrm{nAChR}$ induced an even milder FLNA- $\alpha 7 \mathrm{nAChR}$ association- $\sim 10 \%$ of $\mathrm{A} \beta_{42}$ levels-implying that chronic activation by such agonist drugs could be detrimental. Surprisingly, memantine, an NMDAR and $\alpha 7 \mathrm{nAChR}$ antagonist, was nearly as potent as $A \beta_{40}$ in inducing an FLNA- $\alpha 7 \mathrm{nAChR}$ association, suggesting that this commonly prescribed $\mathrm{AD}$ drug may potentially contribute to disease progression.

$\mathrm{AD}$ postmortem tissue or $\mathrm{A} \beta_{42}$ treatment also shows a dramatic increase in FLNA association with TLR4, the innate immune receptor responsible for inflammatory cytokine release. FLNA recruitment may similarly aid in the signaling of TLR4 because PTI-125 also blocks FLNA-TLR4 association and $\mathrm{A} \beta_{42}$-induced inflammatory cytokine release. 
Although $\mathrm{A} \beta_{42}$ does not itself interact with TLR4, it binds to CD14, which, in turn, binds TLR4 to produce the inflammation noted in $\mathrm{AD}$ (Reed-Geaghan et al., 2009). A common feature of neurodegenerative diseases is chronic immune activation, particularly of microglia (Amor, 2010). Hence, a second therapeutic mechanism of action likely to be highly beneficial in $\mathrm{AD}$ is an anti-inflammatory effect, particularly against $\mathrm{A} \beta$-induced inflammation.

In an ICV A $\beta_{42}$ infusion mouse model of $\mathrm{AD}, \mathrm{A} \beta_{42}$ induced robust FLNA associations with both $\alpha 7 \mathrm{nAChR}$ and TLR4 that were almost completely blocked by 2-week PTI-125 treatment starting shortly after $\mathrm{A} \beta_{42}$ administration. Remarkably, PTI-125 also reversed this FLNA- $\alpha 7 \mathrm{nAChR}$ association in postmortem $\mathrm{AD}$ brain slices and in age-matched control brain tissue incubated with $A \beta_{42}$. The enabling of $A \beta_{42}$ signaling through $\alpha 7 \mathrm{nAChR}$ by the FLNA$\alpha 7 \mathrm{nAChR}$ association is evidenced by a prominent phosphorylation of tau protein at three sites known to be phosphorylated in tau found in NFTs. PTI-125 blockade of FLNA $-\alpha 7 \mathrm{nAChR}$ association dramatically decreased this tau phosphorylation. PTI125 prevention of $\mathrm{A} \beta_{42}$ signaling and tau phosphorylation resulted in a profound reduction of both NFT (phospho-tau) immunoreactivity and $\mathrm{A} \beta_{42}$ aggregates in the FCX and hippocampus of ICV $\mathrm{A} \beta_{42}$-infused mice. The reduction in $\mathrm{A} \beta_{42}$ aggregates in parallel with the reduced NFT formation supports the theory that tau phosphorylation and NFTs are associated with $\mathrm{A} \beta_{42}$ internalization/deposition and eventual plaque formation (Wang et al., 2009). Evidence that the FLNA-TLR4 association is critical to $\mathrm{A} \beta_{42}$-induced TLR4 signaling is the profound reduction in IL-6, TNF- $\alpha$, and IL- $1 \beta$ by PTI-125 in ICV $\mathrm{A} \beta_{42^{-}}$ infused mice.

Importantly, PTI-125 preserves or restores the signaling functions of $\alpha 7 \mathrm{nAChR}$, NMDAR, which is regulated by $\alpha 7$ nAChR (Snyder et al., 2005; Wang et al., 2009), and IR. The signaling capacity of all three receptors is notably impaired in postmortem AD tissue, $A \beta_{42}$-treated postmortem control tissue, and $\mathrm{A} \beta_{42}$-infused mice, and PTI-125 normalized function in each case. Calcium influx after receptor stimulation was used to assess the function of $\alpha 7 \mathrm{nAChR}$ and NMDARs, and signaling was also assessed in NMDARs and IRs by the association of each receptor with several signaling molecules, activated (phosphorylated) or recruited as appropriate. PTI-125 does not alter these receptor functions in the absence of $A \beta_{42}$ because the very low basal levels of FLNA association with $\alpha 7 \mathrm{nAChR}$ or TLR 4 are not altered by PTI-125 (e.g., PTI- 125 treatment of ICV vehicle-infused mice). Clearly, it is important to preserve NMDAR function in $\mathrm{AD}$ because these receptors mediate long-term potentiation (LTP), critical to learning and memory and disrupted by A $\beta$ (Yamin, 2009). $\alpha 7 \mathrm{nAChR}$, though a subtype of acetylcholine receptors, also plays an im-
B
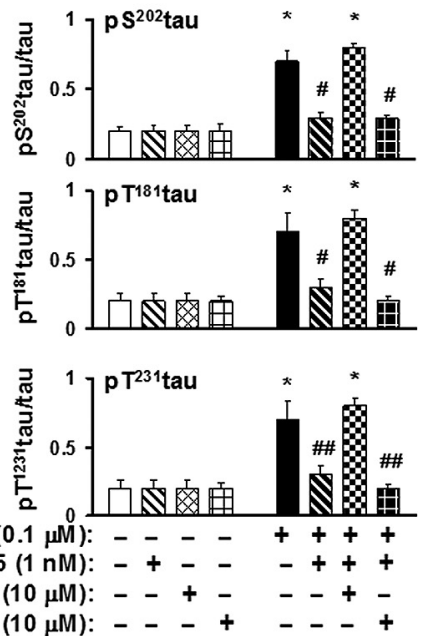

Figure 11. The VAKGL pentapeptide also blocked PTI-125 reduction in $A \beta_{42}$-induced tau phosphorylation at three phosphorPTI-125 reduction of $A \beta_{42}$-induced tau phosphorylation. Western blots $(\boldsymbol{A})$ were analyzed by densitometric quantification $(\boldsymbol{B})$.

A

Figure 12. FLNA associations with $\alpha 7 n A C h R$ and TLR4 were markedly increased in $A D$ and $A \beta_{42}$-treated lymphocytes, and 30 min incubation with PTI-125 reduced these associations. Western blots $(\boldsymbol{A})$ were analyzed by densitometric quantification $(\boldsymbol{B}) . n=$ 2. ${ }^{* *} p<0.05,{ }^{*} p<0.01$ vs vehicle-treated control; ${ }^{\# \#} p<0.05,{ }^{\#} p<0.01$ vs $A \beta_{42}$-treated control or vehicle-treated AD. portant role in cognition and LTP (Timofeeva and Levin, 2011; Wallace and Porter, 2011), and its dysfunction undoubtedly contributes to cognitive decline in AD.

The loss of IR signaling in $\mathrm{AD}$ is a recent focus in $\mathrm{AD}$ research, underscoring the comorbidity of $\mathrm{AD}$ and type 2 diabetes mellitus. Type 2 diabetes mellitus appears to be a significant risk factor for AD (Biessels et al., 2006; Profenno et al., 2010; Schrijvers et al., 2010; Bosco et al., 2011), likely because insulin signaling in the CNS regulates cell survival. Decreased insulin signaling leaves cells vulnerable to oxidative stress and other metabolic insults and can increase inflammation and even tau phosphorylation (Bosco et al., 2011). Experimental diabetes mellitus exacerbates tau pathology in a transgenic mouse model of $\mathrm{AD}$ (Ke et al., 2009). The diabetes drug liraglutide has been shown to decrease neuropathology in a transgenic mouse model of AD (McClean et al., 2011), suggesting possible usefulness in AD. PTI-125 does not directly interact with IRs, and though FLNA interacts with IR, this interaction is unchanged by $\mathrm{A} \beta_{42}$ or PTI- 125 . However, $\mathrm{A} \beta_{42}$ and PTI-125 may both alter the conformation of FLNA to respec- 


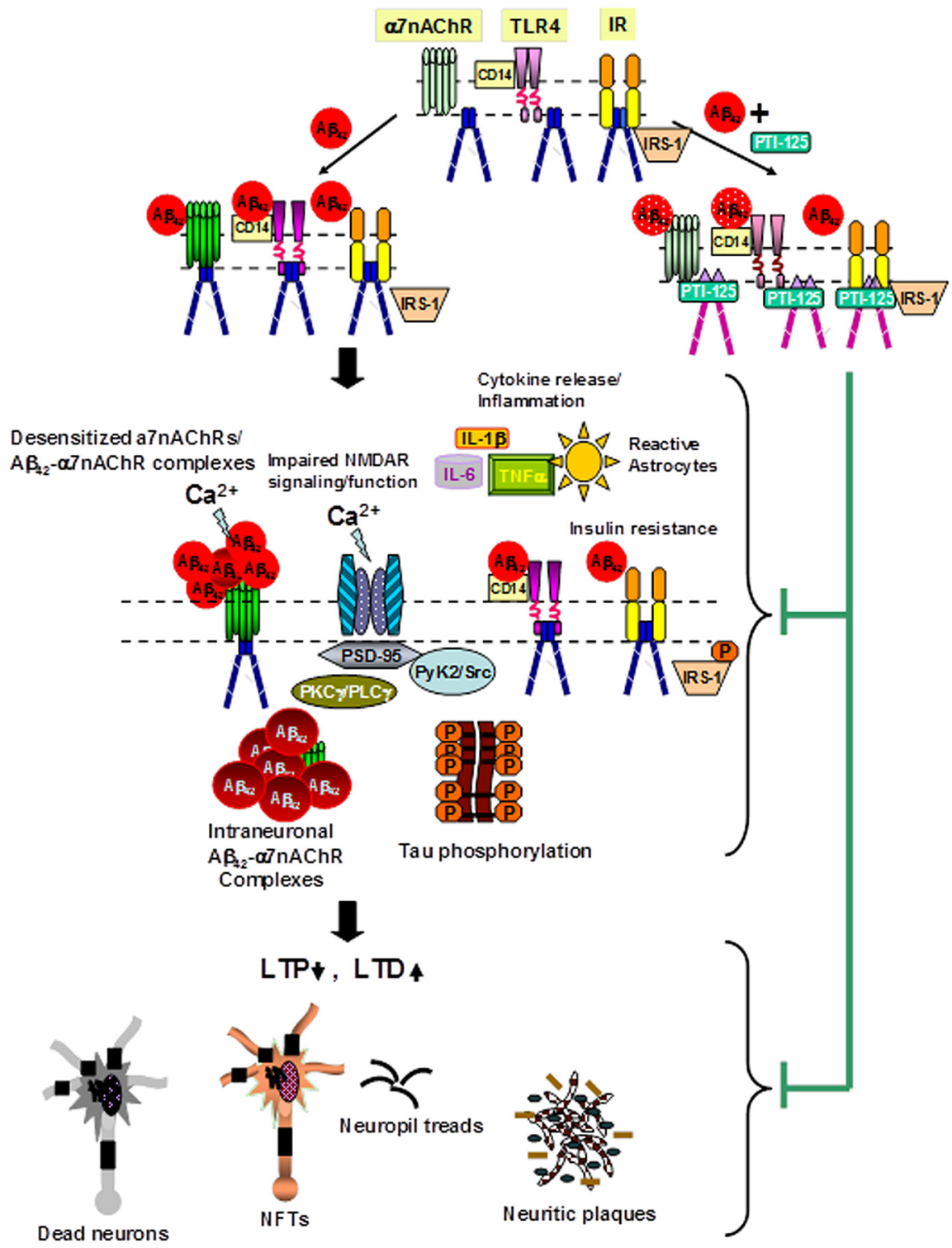

Figure 13. Proposed model of PTI- 125 normalizing $A \beta_{42}$-induced synaptic dysfunction. Soluble $A \beta_{42}$ or $A \beta_{42}$ oligomers bind to $\alpha 7 \mathrm{nAChRs}$ in AD brains to induce synaptic dysfunction by first activating $\alpha 7 \mathrm{nAChRs}$ (Dougherty et al., 2003) and TLR4s (Lotz et al., 2005) (by CD14) to recruit FLNA, which enables a high-affinity interaction of $A \beta_{42}$ with these receptors. The result of FLNA recruitment to TLR4 is enhanced signaling and cytokine release. With FLNA recruited to $\alpha 7 \mathrm{nAChR}, A \beta_{42}$ binding activates kinases that leads to rapid tau phosphorylation and neurofibrillary lesions (Wang et al., 2003) and causes desensitization, restricting $\mathrm{Ca}^{2+}$ influx through $\alpha 7 \mathrm{nAChRs}$ and impairing downstream NMDAR activity and signaling. In addition, $\mathrm{A} \beta_{42}$ oligomers acting through multiple pathways impair IR function, leading to insulin resistance in neuronal cells (Zhao et al., 2008). Similar to a partial pharmacological blockade of NMDARs, $A \beta_{42}$-induced hypofunctioning NMDARs are expected to reduce NMDAR-dependent LTP and to increase LTD, leading to dendritic spine shrinkage and retraction (Shankar et al., 2007) that further dampens excitatory neurotransmission. By binding to a defined pentapeptide binding domain with high affinity, PTI-125 may elicit conformational changes in FLNA to prevent its recruitment to $\alpha 7 \mathrm{nAChRs}$ and TLR4s, thereby reducing $\mathrm{A} \beta_{42}$ affinity and facilitating the dissociation of $A \beta_{42}$ from these receptors. The normalized $\alpha 7 \mathrm{nAChR}$ and TLR4 activities improve NMDAR activation and reduce cytokine release (inflammation). Although neither $A \beta_{42}$ nor PTI-125 alters FLNA recruitment to IRs, the PTI-125-induced conformational change in FLNA restores $A \beta_{42}$-suppressed IR function and lessens insulin resistance. The augmented NMDAR activation favors LTP induction and healthier dendritic spines, resulting in more normal excitatory neurotransmission and cognitive processing. The improved IR function leads to healthier cells. Together, PTI-125 treatment lessens neurodegeneration and reduces the burdens of neuritic plaques and neurofibrillary tangles. Changes in color and shape of receptors and FLNA represent conformational or affinity changes.

tively impair and restore IR signaling. It is also possible that $\mathrm{A} \beta_{42^{-}}$ induced IR signaling impairments are a result of $\mathrm{A} \beta_{42}$-induced inflammation because inflammation and inflammatory cytokines such as TNF- $\alpha$ and IL- 6 are causally linked to insulin resistance (Wellen and Hotamisligil, 2005; de Luca and Olefsky,
2008). The restoration of IR signaling function by PTI- 125 could be the result of decreased inflammatory cytokines through the suppression of TLR4 signaling. The restoration of IR signaling is another important therapeutic aspect of PTI-125.

Finally, the femtomolar-to-nanomolar affinity shift in $\mathrm{A} \beta_{42}$ interaction with $\alpha 7 \mathrm{nAChR}$ induced by PTI- 125 represents a novel mechanism of action, occurring indirectly by FLNA. The effects of PTI125 are clearly dependent on its binding to FLNA because both the FLNA$\alpha 7 \mathrm{nAChR} / \mathrm{TLR} 4$ association and tau phosphorylation can be blocked in $\mathrm{A} \beta_{42^{-}}$ treated control postmortem tissue by the addition of a decoy pentapeptide that is the compound's binding site on FLNA. Thus far, the best attempt to directly displace $\mathrm{A} \beta_{42}$ from $\alpha 7 \mathrm{nAChR}$ has yielded more modest effects on tau phosphorylation and in vitro requires incubation 10 min before exposure to $A \beta_{42}$ to compete with its femtomolar affinity for $\alpha 7 \mathrm{nAChR}$ (Wang et al., 2010). PTI-125 dramatically reduces this extraordinarily high affinity of $\mathrm{A} \beta_{42}$ binding indirectly by binding FLNA, which apparently is required to stabilize $\mathrm{A} \beta_{42}$ binding. Hence, PTI-125 can help release $\mathrm{A} \beta_{42}$ already bound to $\alpha 7 \mathrm{nAChR}$, as evidenced by the reduction in $\mathrm{A} \beta_{42}-\alpha 7 \mathrm{nAChR}$ complexes in postmortem $\mathrm{AD}$ tissue. This attribute represents a distinct advantage among $\mathrm{AD}$ therapeutic candidates because it implies the potential for some cognitive recovery in addition to slowing or halting disease progression.

The fact that dramatic increases in FLNA- $\alpha 7 \mathrm{nAChR}$ and TLR4 associations and in $\mathrm{A} \beta_{42}-\alpha 7 \mathrm{nAChR}$ complexes were found not just in brain but also in lymphocytes of $\mathrm{AD}$ patients suggests that some high threshold level of these FLNA associations could potentially serve as a noninvasive, blood-based AD diagnostic. Furthermore, PTI-125 reduction of these associations after ex vivo incubation of lymphocytes suggests the usefulness of FLNA- $\alpha 7 \mathrm{nAChR/TLR} 4$ as a biomarker during treatment. Current thinking points to the need for several different simultaneous approaches to treat $\mathrm{AD}$, clearly a disease with multifaceted pathologies. PTI-125's novel and effective mechanism of disrupting $\mathrm{A} \beta_{42}$-induced $\alpha 7 \mathrm{nAChR}$ and TLR4 signaling produces a multitude of therapeutic effects, re-emphasizing the critical roles of $\mathrm{A} \beta_{42}-\alpha 7 \mathrm{nAChR}$ signaling and inflammation in $\mathrm{AD}$. With its attenuation of $\mathrm{A} \beta$-driven tau phosphorylation, normalization of multiple receptor functions, and powerful anti-inflammatory activity, PTI-125 shows great potential as a disease-modifying therapeutic for $\mathrm{AD}$. 


\section{References}

Amor S, Puentes F, Baker D, van der Valk P (2010) Inflammation in neurodegenerative diseases. Immunology 129:154-169.

Biessels GJ, Staekenborg S, Brunner E, Brayne C, Scheltens P (2006) Risk of dementia in diabetes mellitus: a systematic review. Lancet Neurol 5:64-74.

Bosco D, Fava A, Plastino M, Montalcini T, Pujia A (2011) Possible implications of insulin resistance and glucose metabolism in Alzheimer's disease pathogenesis. J Cell Mol Med 15:1807-1821.

Bouzat C, Bartos M, Corradi J, Sine SM (2008) The interface between extracellular and transmembrane domains of homomeric Cys-loop receptors governs open-channel lifetime and rate of desensitization. J Neurosci 28:7808-7819.

Chen L, Yamada K, Nabeshima T, Sokabe M (2006) alpha7 Nicotinic acetylcholine receptor as a target to rescue deficit in hippocampal LTP induction in beta-amyloid infused rats. Neuropharmacology 50:254-268.

D'Andrea MR, Nagele RG, Wang HY, Peterson PA, Lee DH (2001) Evidence that neurones accumulating amyloid can undergo lysis to form amyloid plaques in Alzheimer's disease. Histopathology 38:120-134.

de Luca C, Olefsky JM (2008) Inflammation and insulin resistance. FEBS Lett 582:97-105.

Dougherty JJ, Wu J, Nichols RA (2003) $\beta$-Amyloid regulation of presynaptic nicotinic receptors in rat hippocampus and neocortex. J Neurosci 23:6740-6747.

Dziewczapolski G, Glogowski CM, Masliah E, Heinemann SF (2009) Deletion of the $\alpha 7$ nicotinic acetylcholine receptor gene improves cognitive deficits and synaptic pathology in a mouse model of Alzheimer's disease. J Neurosci 29:8805-8815.

Hyman BT, Trojanowski JQ (1997) Consensus recommendations for the postmortem diagnosis of Alzheimer's disease: the National Institute on Aging, and Reagan Institute Working Group on Diagnostic Criteria for the Neuropathological Assessment of Alzheimer's disease. J Neuropathol Exp Neurol 56:1095-1097.

Ke YD, Delerue F, Gladbach A, Götz J, Ittner LM (2009) Experimental diabetes mellitus exacerbates tau pathology in a transgenic mouse model of Alzheimer's disease. PLoS One 4:e7917.

Lee DH, Wang HY (2003) Differential physiologic responses of alpha7 nicotinic acetylcholine receptors to beta-amyloid $1-40$ and beta-amyloid142. J Neurobiol 55:25-30.

Liu Q, Kawai H, Berg DK (2001) $\beta$-Amyloid peptide blocks the response of $\alpha 7$-containing nicotinic receptors on hippocampal neurons Proc Natl Acad Sci U S A 98:4734-4739.

Lotz M, Ebert S, Esselmann H, Iliev AI, Prinz M, Wiazewicz N, Wiltfang J, Gerber J, Nau R (2005) Amyloid beta peptide 1-40 enhances the action of Toll-like receptor- 2 and -4 agonists but antagonizes Toll-like receptor9-induced inflammation in primary mouse microglial cell cultures. J Neurochem 94:289-298.

McClean PL, Parthsarathy V, Faivre E, Hölscher C (2011) The diabetes drug liraglutide prevents degenerative processes in a mouse model of Alzheimer's disease. J Neurosci 31:6587-6594.

McKhann G, Drachman D, Folstein M, Katzman R, Price D, Stadlan EM (1984) Clinical diagnosis of Alzheimer's disease: Report of the NINCDSADRDA Work Group under the auspices of Department of Health and Human Services Task Force on Alzheimer's disease. Neurology 34:939-944.

Nagele RG, D'Andrea MR, Anderson WJ, Wang HY (2002) Accumulation of beta-amyloid $1-42$ in neurons is facilitated by the alpha7 nicotinic acetylcholine receptor in Alzheimer's disease. Neuroscience 110:199-211.

Näslund J, Haroutunian V, Mohs R, Davis KL, Davies P, Greengard P, Buxbaum JD (2000) Correlation between elevated levels of amyloid betapeptide in the brain and cognitive decline. JAMA 283:1571-1577.

Pettit DL, Shao Z, Yakel JL (2001) $\beta$-Amyloid(1-42) peptide directly mod- ulates nicotinic receptors in the rat hippocampal slice. J Neurosci 21:RC120-RC125.

Profenno LA, Porsteinsson AP, Faraone SV (2010) Meta-analysis of Alzheimer's disease risk with obesity, diabetes, and related disorders. Biol Psychiatry 67:505-512.

Reed-Geaghan EG, Savage JC, Hise AG, Landreth GE (2009) CD14 and tolllike receptors 2 and 4 are required for fibrillar $A \beta$-stimulated microglial activation. J Neurosci 29:11982-11992.

Schrijvers EM, Witteman JC, Sijbrands EJ, Hofman A, Koudstaal PJ, Breteler MM (2010) Insulin metabolism and the risk of Alzheimer disease: the Rotterdam Study. Neurology 75:1982-1987.

Shankar GM, Bloodgood BL, Townsend M, Walsh DM, Selkoe DJ, Sabatini BL (2007) Natural oligomers of the Alzheimer amyloid-beta protein induce reversible synaptic loss by modulating an NMDA-type glutamate receptor-dependent signaling pathway. J Neurosci 27:2866-2875.

Snyder EM, Nong Y, Almeida CG, Paul S, Moran T, Choi EY, Nairn AC, Salter MW, Lombroso PJ, Gouras GK, Greengard P (2005) Regulation of NMDA receptor trafficking by amyloid-beta. Nat Neurosci 8:1051-1058.

Stossel T, Condeelis J, Cooley L, Hartwig J, Noegel A, Schleicher M, Shapiro S (2001) Filamins as integrators of cell mechanics and signalling. Nat Rev Mol Cell Biol 2:138-145.

Timofeeva OA, Levin ED (2011) Glutamate and nicotinic receptor interactions in working memory: importance for the cognitive impairment of schizophrenia. Neuroscience 195:21-36.

Trojanowski JQ, Vandeerstichele H, Korecka M, Clark CM, Aisen PS, Petersen RC, Kaj Blennow K, Soares H, Simon A, Lewczuk P, Dean R, Siemers E, Potter WZ, Weiner MW, Jack CR Jr, Jagust W, Toga AW, Lee VM, Shaw LM (2010) Update on the Biomarker Core of the Alzheimer's Disease Neuroimaging Initiative Subjects. Alzheimers Dement 6:230-238.

Wallace TL, Porter RH (2011) Targeting the nicotinic alpha7 acetylcholine receptor to enhance cognition in disease. Biochem Pharmacol 82:891-903.

Wang HY, Lee DH, Davie CB, Shank RP (2000a) Amyloid peptide A $\beta 1-42$ binds selectively and with picomolar affinity to $\alpha 7$ nicotinic acetylcholine receptors. J Neurochem 75:1155-1161.

Wang HY, Lee DH, D'Andrea MR, Peterson PA, Shank RP, Reitz AB (2000b) $\beta$-Amyloid1-42 binds to $\alpha 7$ nicotinic acetylcholine receptor with high affinity: implications for Alzheimer's disease pathology. J Biol Chem 275:5626-5632.

Wang HY, Li W, Benedetti NJ, Lee DH (2003) $\alpha 7$ Nicotinic acetylcholine receptors mediate $\beta$-amyloid peptide-induced tau protein phosphorylation. J Biol Chem 278:31547-31553.

Wang HY, Stucky A, Liu J, Shen C, Trocme-Thibierge C, Morain P (2009) Dissociating beta-amyloid from alpha 7 nicotinic acetylcholine receptor by a novel therapeutic agent, S 24795, normalizes alpha 7 nicotinic acetylcholine and NMDA receptor function in Alzheimer's disease brain. J Neurosci 35:10961-10973.

Wang HY, Bakshi K, Shen C, Frankfurt M, Trocmé-Thibierge C, Morain P (2010) S 24795 limits $\beta$-amyloid- $\alpha 7$ nicotinic receptor interaction and reduces Alzheimer's disease-like pathologies. Biol Psychiatry 67:522-530.

Wellen KE, Hotamisligil GS (2005) Inflammation, stress, and diabetes. J Clin Invest 115:1111-1119.

Wimo A, Prince M (2010) World Alzheimer report 2010: the global economic impact of dementia. London: Alzheimer's Disease International.

Yamamoto T, Hirano A (1986) A comparative study of modified Bielschowsky, Bodian and thioflavin S stains on Alzheimer's neurofibrillary tangles. Neuropathol Appl Neurobiol 12:3-9.

Yamin G (2009) NMDA receptor-dependent signaling pathways that underlie amyloid beta-protein disruption of LTP in the hippocampus. J Neurosci Res 87:1729-1736.

Zhao W, De Felice F, Fernandez S, Chen H, Lambert M, Quon M, Krafft G, Klein W (2008) Amyloid beta oligomers induce impairment of neuronal insulin receptors. FASEB J 22:246-260. 